\title{
LEVEL II SCOUR ANALYSIS FOR BRIDGE 10 (GRAFTH00020010) on TOWN HIGHWAY 2 (VT 121), crossing the SAXTONS RIVER, GRAFTON, VERMONT
}

U.S. Geological Survey Open-File Report 98-538

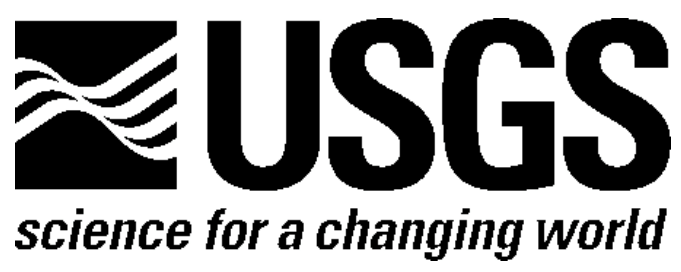


LEVEL II SCOUR ANALYSIS FOR

BRIDGE 10 (GRAFTH00020010) on

TOWN HIGHWAY 2 (VT 121), crossing the SAXTONS RIVER,

GRAFTON, VERMONT

By ERICK M. BOEHMLER AND ROBERT E. HAMMOND

U.S. Geological Survey

Open-File Report 98-538

Prepared in cooperation with

VERMONT AGENCY OF TRANSPORTATION

and

FEDERAL HIGHWAY ADMINISTRATION 


\title{
U.S. DEPARTMENT OF THE INTERIOR BRUCE BABBITT, Secretary
}

\author{
U.S. GEOLOGICAL SURVEY
}

Thomas J. Casadevall, Acting Director

For additional information write to:

District Chief

U.S. Geological Survey 361 Commerce Way

Pembroke, NH 03275-3718
Copies of this report may be purchased from:

U.S. Geological Survey

Branch of Information Services

Open-File Reports Unit

Box 25286

Denver, CO 80225-0286 


\section{CONTENTS}

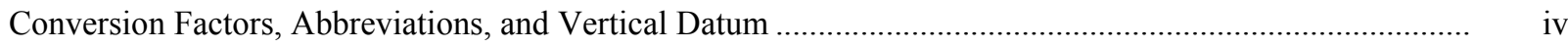

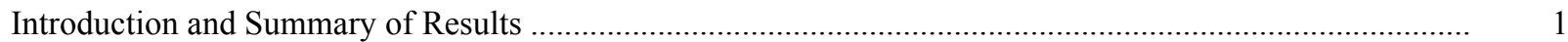

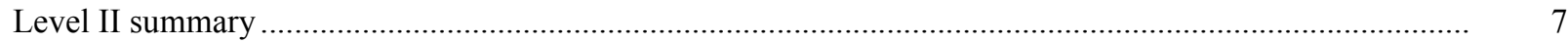

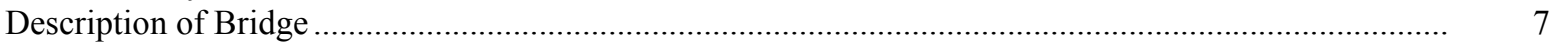

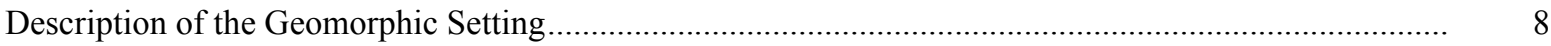

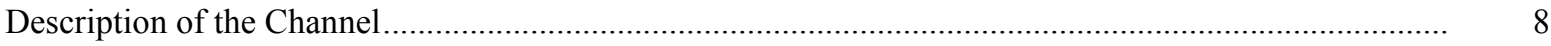

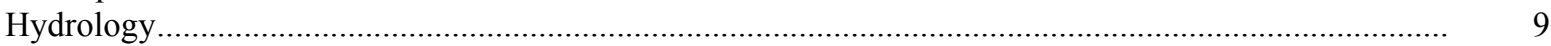

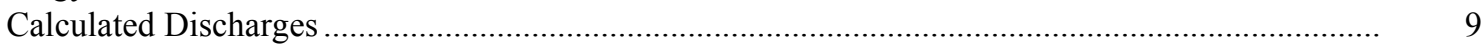

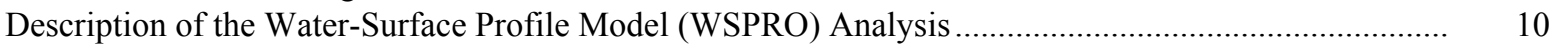

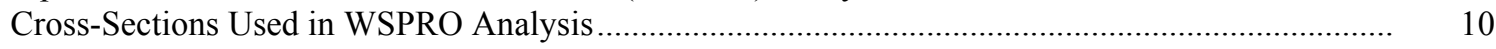

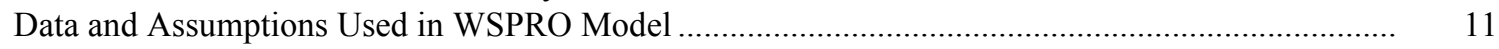

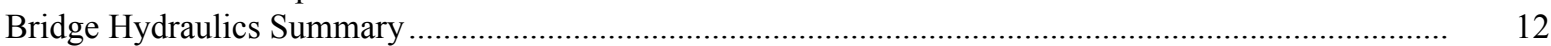

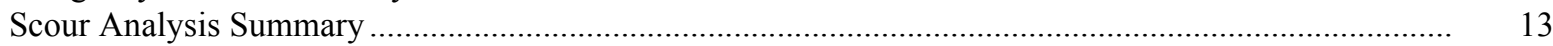

Special Conditions or Assumptions Made in Scour Analysis ..................................................... 13

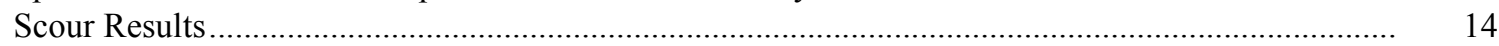

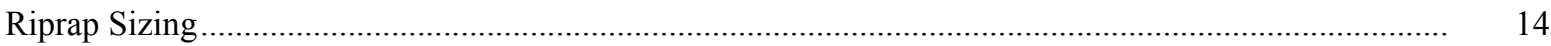

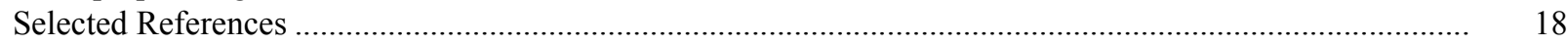

Appendices:

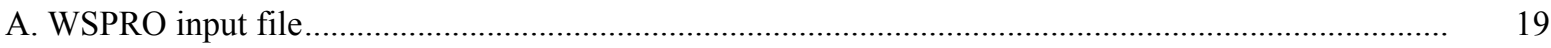

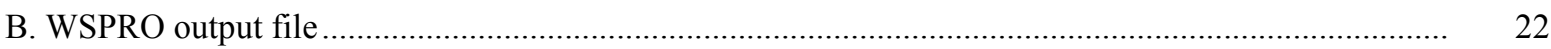

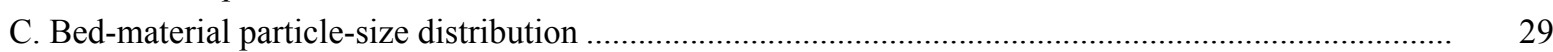

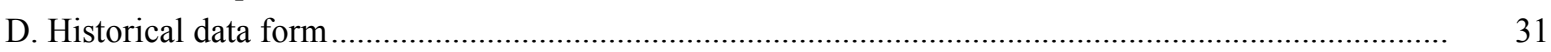

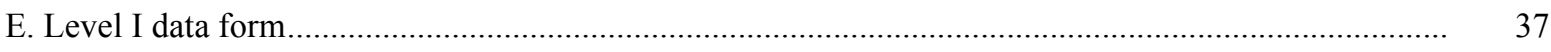

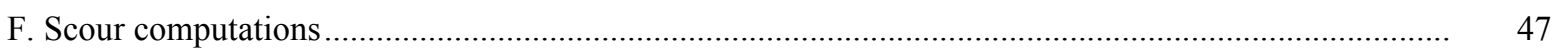

\section{FIGURES}

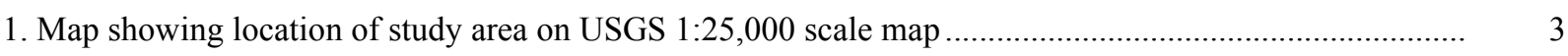

2. Map showing location of study area on Vermont Agency of Transportation town

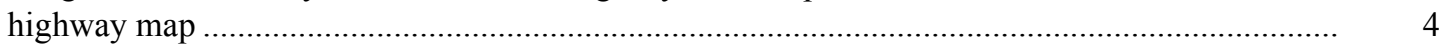

3. Structure GRAFTH00020010 viewed from upstream (August 21, 1996) .......................................... 5

4. Downstream channel viewed from structure GRAFTH00020010 (August 21, 1996)........................... 5

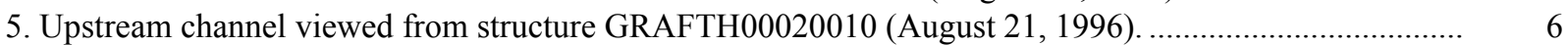

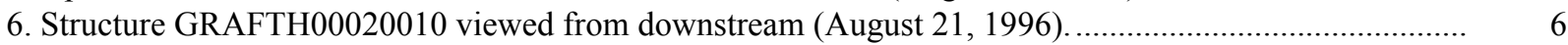

7. Water-surface profiles for the 100- and 500-year discharges at structure

GRAFTH00020010 on Town Highway 2, crossing the Saxtons River,

Grafton, Vermont.

8. Scour elevations for the 100- and 500-year discharges at structure

GRAFTH00020010 on Town Highway 2, crossing the Saxtons River,

Grafton, Vermont.

\section{TABLES}

1. Remaining footing/pile depth at abutments for the 100-year discharge at structure

GRAFTH00020010 on Town Highway 2, crossing the Saxtons River,

Grafton, Vermont

2. Remaining footing/pile depth at abutments for the 500-year discharge at structure

GRAFTH00020010 on Town Highway 2, crossing the Saxtons River,

Grafton, Vermont 


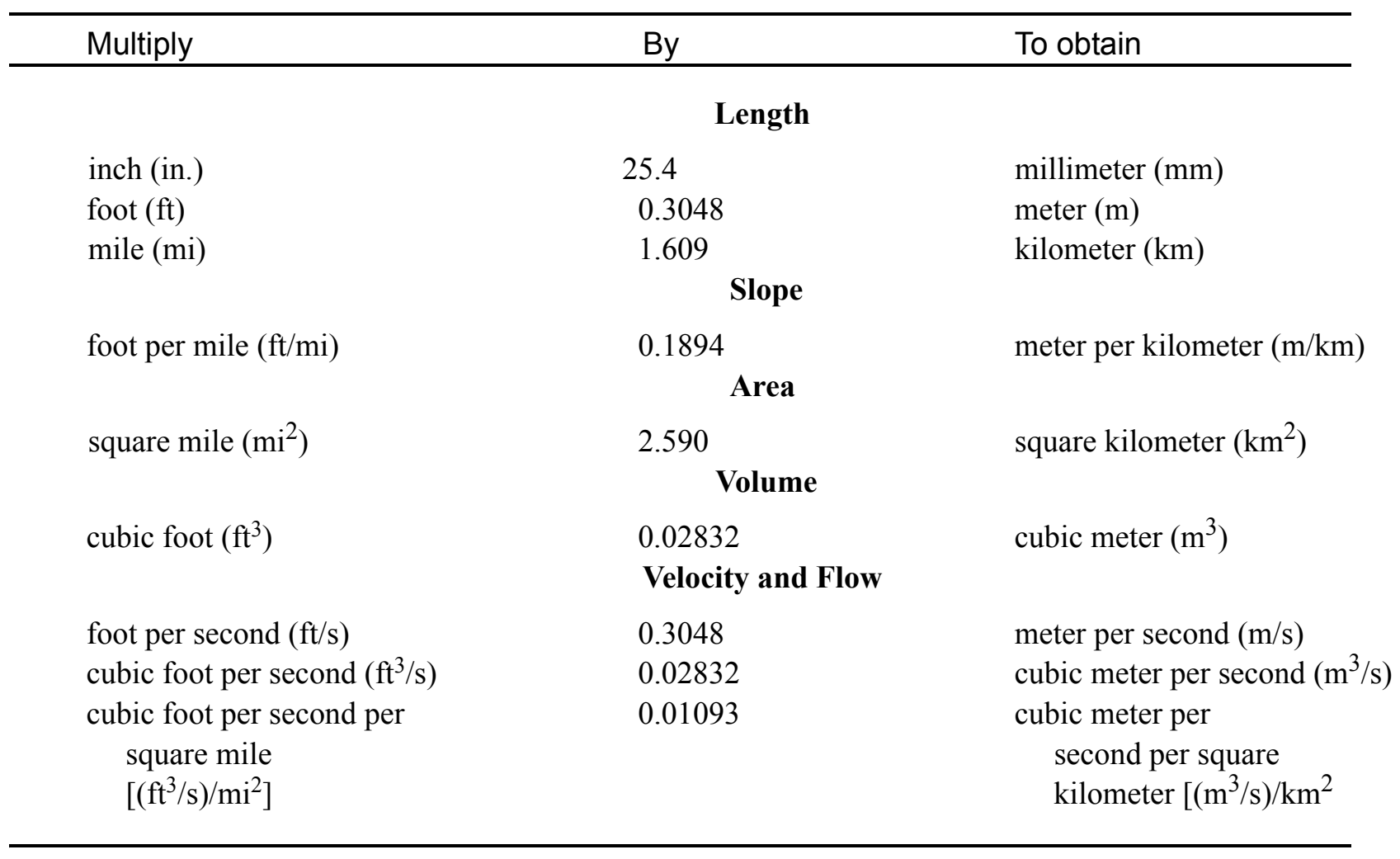

\section{OTHER ABBREVIATIONS}

$\begin{array}{lrlr}\mathrm{BF} & \begin{array}{r}\text { bank full } \\ \mathrm{cfs}\end{array} & \text { LWW } & \text { left wingwall } \\ \mathrm{D}_{50} & \begin{array}{r}\text { cubic feet per second } \\ \text { maximum }\end{array} \\ \mathrm{DS} & \text { Max } & \text { main channel } \\ \mathrm{elev} & \text { downstream } & \text { RAB } & \text { riameter of bed material } \\ \mathrm{f} / \mathrm{p} & \text { elevation } & \text { RABUT } & \text { floce of right abutment } \\ \mathrm{ft}^{2} & \text { flood plain } & \text { RB } & \text { right bank } \\ \mathrm{ft} / \mathrm{ft} & \text { square feet } & \text { ROB } & \text { right overbank } \\ \mathrm{FEMA} & \text { feet per foot } & \text { RWW } & \text { right wingwall } \\ \text { FHWA } & \text { Federal Emergency Management Agency } & \text { TH } & \text { town highway } \\ \text { JCT } & \text { Federal Highway Administration } & \text { UB } & \text { under bridge } \\ \text { LAB } & \text { junction } & \text { US } & \text { upstream } \\ \text { LABUT } & \text { left abutment } & \text { USGS } & \text { United States Geological Survey } \\ \text { LB } & \text { face of left abutment } & \text { VTAOT } & \text { Vermont Agency of Transportation } \\ \text { LOB } & \text { left bank } & \text { WSPRO } & \text { water-surface profile model } \\ & \text { left overbank } & \text { yr } & \text { year }\end{array}$

In this report, the words "right" and "left" refer to directions that would be reported by an observer facing downstream. Sea level: In this report, "sea level" refers to the National Geodetic Vertical Datum of 1929-- a geodetic datum derived from a general adjustment of the first-order level nets of the United States and Canada, formerly called Sea Level Datum of 1929.

In the appendices, the above abbreviations may be combined. For example, USLB would represent upstream left bank. 


\title{
LEVEL II SCOUR ANALYSIS FOR BRIDGE 10 (GRAFTH00020010) ON TOWN HIGHWAY 2 (VT 121), CROSSING THE SAXTONS RIVER, GRAFTON, VERMONT
}

\author{
By Erick M. Boehmler And Robert E. Hammond
}

\section{INTRODUCTION AND SUMMARY OF RESULTS}

This report provides the results of a detailed Level II analysis of scour potential at structure GRAFTH00020010 on Town Highway 2 crossing the Saxtons River, Grafton, Vermont (figures 1-8). Town Highway 2 also is designated as State Route 121. A Level II study is a basic engineering analysis of the site, including a quantitative analysis of stream stability and scour (Federal Highway Administration, 1993). Results of a Level I scour investigation also are included in appendix $\mathrm{E}$ of this report. A Level I investigation provides a qualitative geomorphic characterization of the study site. Information on the bridge, gleaned from Vermont Agency of Transportation (VTAOT) files, was compiled prior to conducting Level I and Level II analyses and is found in appendix D.

The site is in the New England Upland section of the New England physiographic province in Southeastern Vermont. The $10.8-\mathrm{mi}^{2}$ drainage area is in a predominantly rural and forested basin. In the vicinity of the study site, the surface cover consists of forest on the upstream left bank, brush on the upstream right bank and row crops on both banks downstream.

In the study area, the Saxtons River has an incised, straight channel with a slope of approximately $0.01 \mathrm{ft} / \mathrm{ft}$, an average channel top width of $50 \mathrm{ft}$ and an average bank height of $7 \mathrm{ft}$. The channel bed materials range from sand to boulders with a median grain size $\left(\mathrm{D}_{50}\right)$ of $57.0 \mathrm{~mm}(0.187 \mathrm{ft})$. The geomorphic assessment at the time of the Level I and Level II site visit on August 21, 1996, indicated that the reach was stable.

The Town Highway 2 crossing of the Saxtons River is a 52-ft-long, two-lane bridge consisting of one 50-foot concrete span (Vermont Agency of Transportation, written communication, March 29, 1995). The opening length of the structure parallel to the bridge face is 46.9 feet. The bridge is supported by vertical, concrete abutments with wingwalls. The channel is skewed approximately 60 degrees to the opening while the computed opening-skew-to-roadway is 45 degrees. 
A scour hole 1.0 foot deeper than the mean thalweg depth was observed along the left bank protection upstream of and under the bridge during the Level I assessment. Another scour hole 0.5 feet deeper than the mean thalweg depth was observed at the downstream end of the left abutment wall. The only scour protection measure at the site was type- 2 stone fill (less than 36 inches diameter) on the left and right banks upstream and downstream of the bridge and on all four wingwalls. Additional details describing conditions at the site are included in the Level II Summary and appendices D and E.

Scour depths and recommended rock rip-rap sizes were computed using the general guidelines described in Hydraulic Engineering Circular 18 (Richardson and Davis, 1995) for the 100- and 500-year discharges. In addition, the incipient roadway-overtopping discharge was determined and analyzed as another potential worst-case scour scenario. Total scour at a highway crossing is comprised of three components: 1) long-term streambed degradation; 2) contraction scour (due to accelerated flow caused by a reduction in flow area at a bridge) and; 3 ) local scour (caused by accelerated flow around piers and abutments). Total scour is the sum of the three components. Equations are available to compute depths for contraction and local scour and a summary of the results of these computations follows.

Contraction scour for all modelled flows ranged from 0 to $1.4 \mathrm{ft}$. The worst-case contraction scour occurred at the incipient roadway-overtopping discharge, which was less than the 100-year discharge. Abutment scour ranged from 5.7 to $14.2 \mathrm{ft}$. The worst-case abutment scour occurred at the 500-year discharge. Additional information on scour depths and depths to armoring are included in the section titled "Scour Results". Scoured-streambed elevations, based on the calculated scour depths, are presented in tables 1 and 2. A crosssection of the scour computed at the bridge is presented in figure 8. Scour depths were calculated assuming an infinite depth of erosive material and a homogeneous particle-size distribution.

It is generally accepted that the Froehlich equation (abutment scour) gives "excessively conservative estimates of scour depths" (Richardson and Davis, 1995, p. 47). Usually, computed scour depths are evaluated in combination with other information including (but not limited to) historical performance during flood events, the geomorphic stability assessment, existing scour protection measures, and the results of the hydraulic analyses. Therefore, scour depths adopted by VTAOT may differ from the computed values documented herein. 


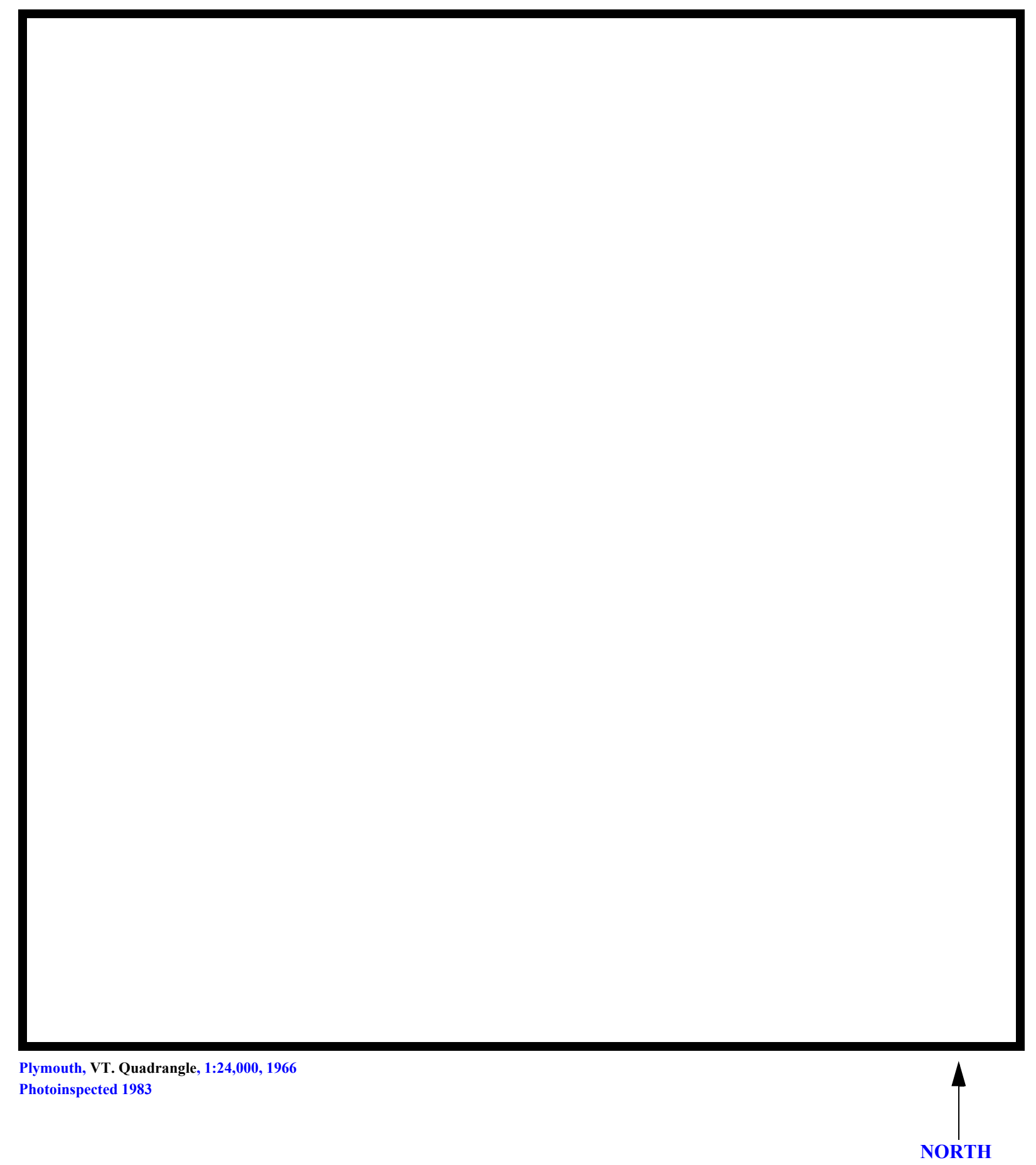

Figure 1. Location of study area on USGS 1:24,000 scale map. 
Figure 2. Location of study area on Vermont Agency of Transportation town highway map. 

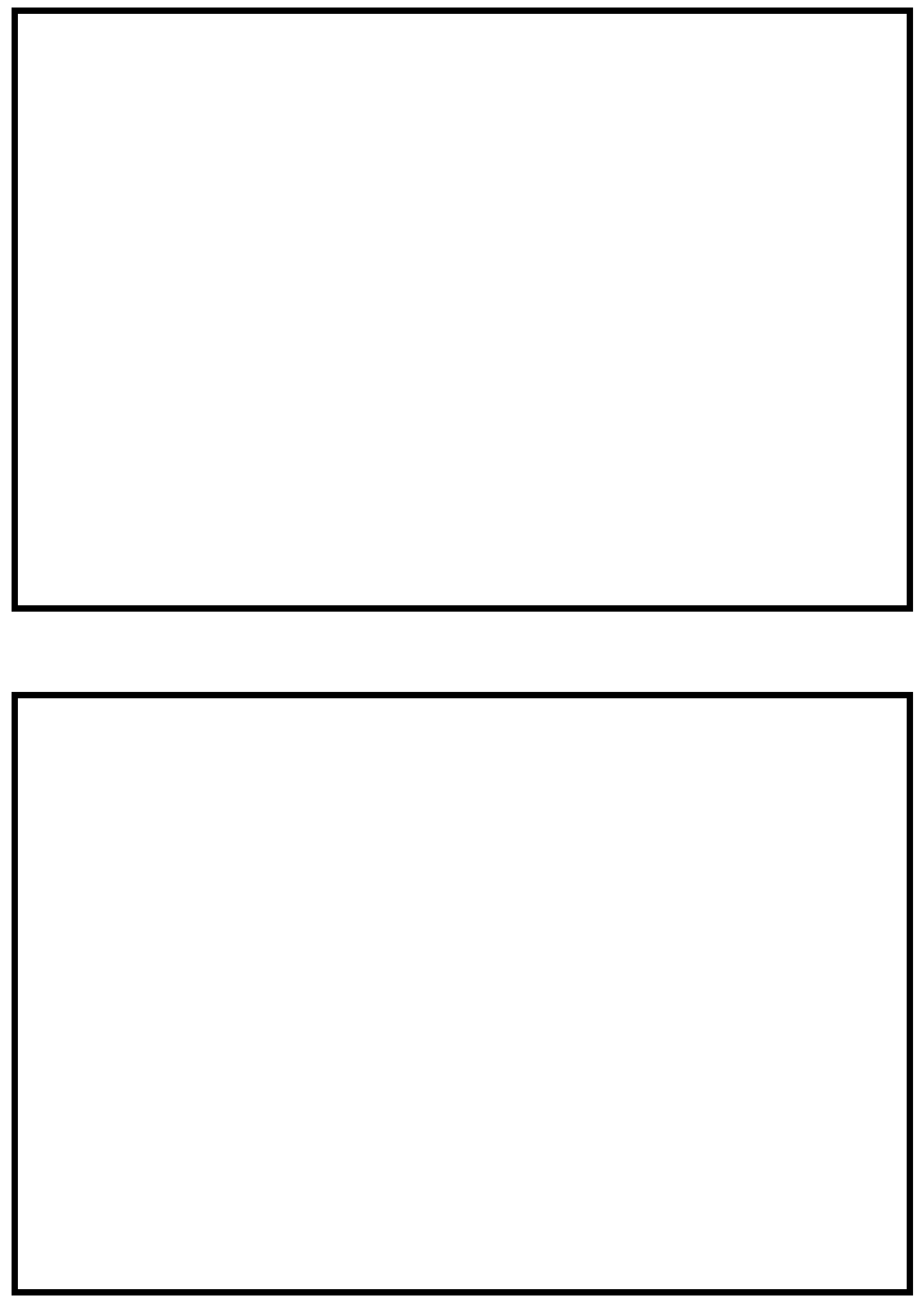

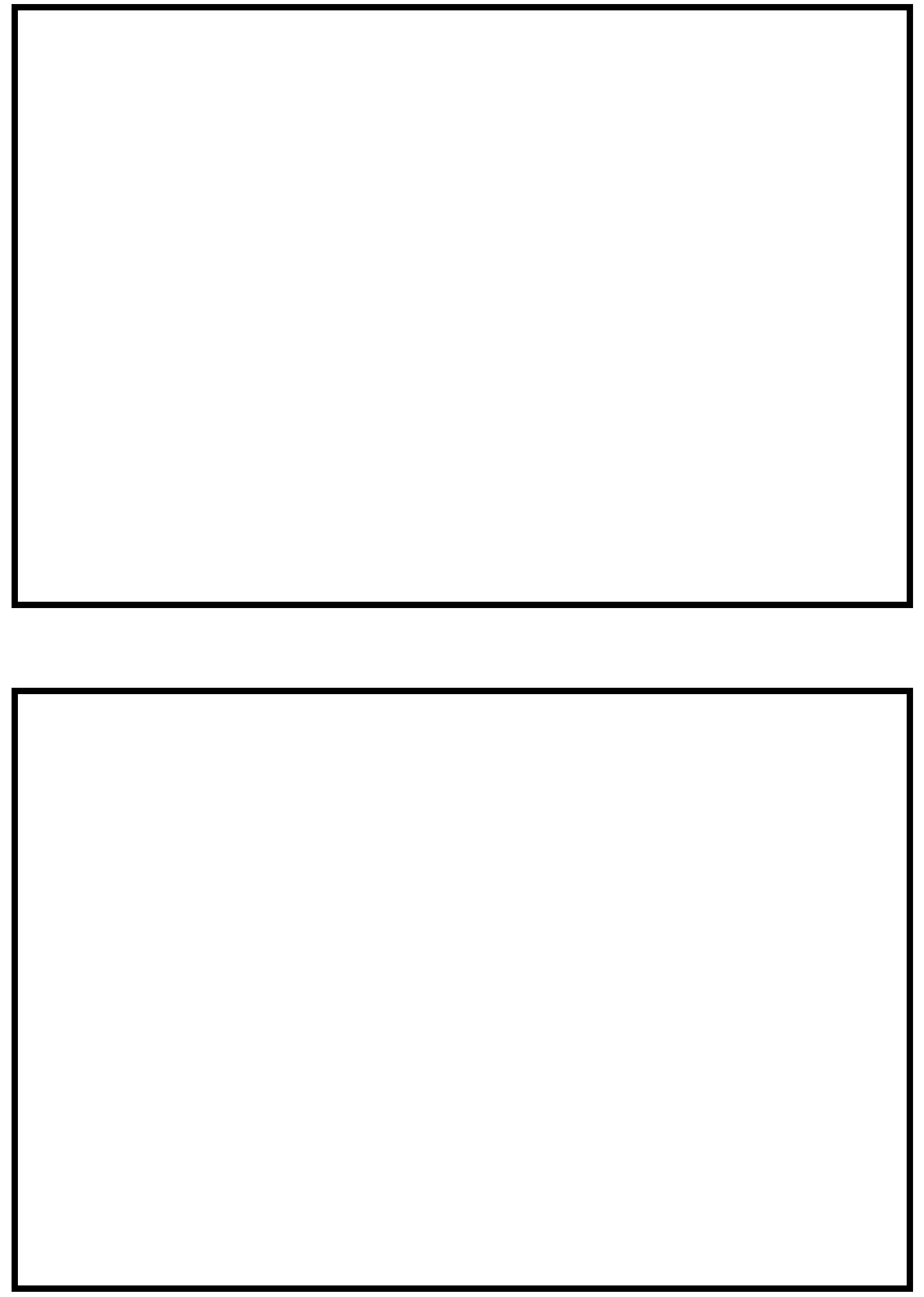


\section{LEVEL II SUMMARY}

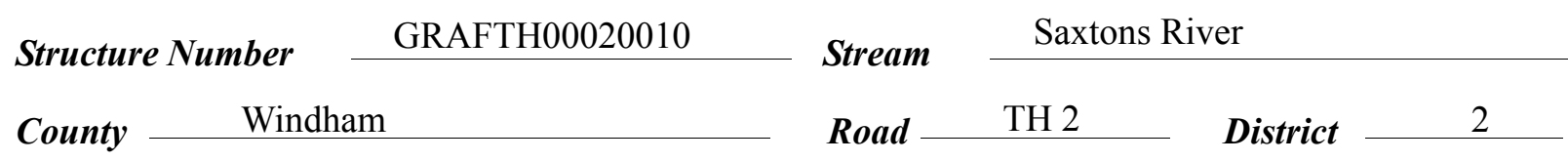

\section{Description of Bridge}

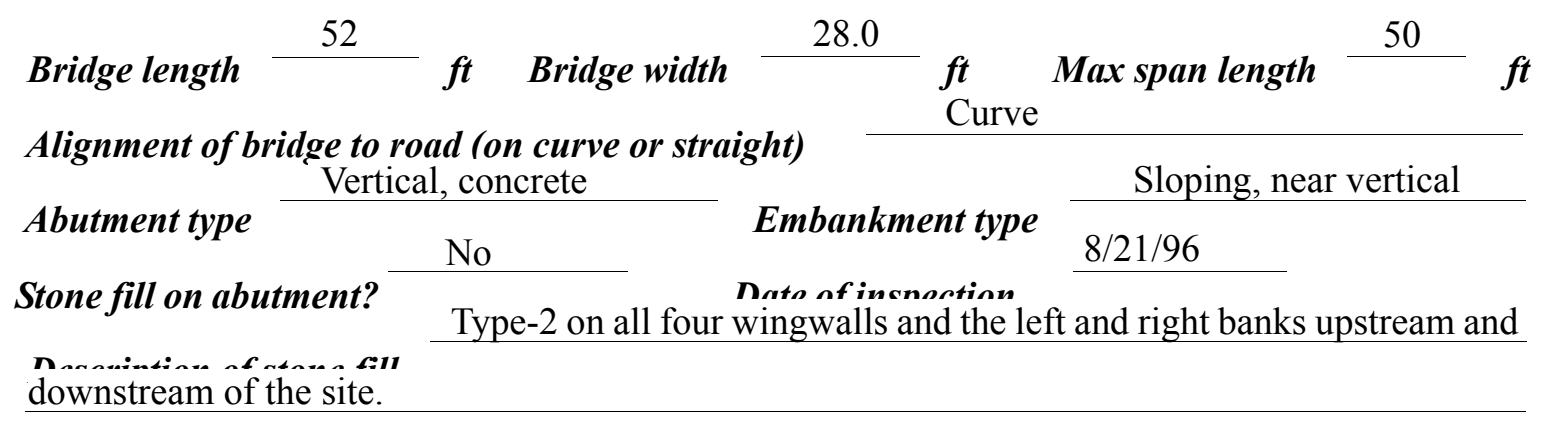

Abutments and wingwalls are concrete. There is a onehalf foot deep scour hole at the downstream end of the left abutment and a 1-foot deep scour holy along the upstream end of the left abutment.

Yes

Is bridge skewed to flood flow according to Yes 'survey? Angle

There is a mild channel bend in the upstream reach. The scour hole has developed in the location where the flow impacts the upstream left bank protection.

Debris accumulation on bridge at time of Level I or Level II site visit:

\begin{tabular}{|c|c|c|c|}
\hline & $\begin{array}{c}\text { Date of insnortion } \\
8 / 21 / 96 \\
\end{array}$ & $\begin{array}{l}\text { Percent of alommat } \\
\text { blocked inortzontatly }\end{array}$ & $\begin{array}{l}\text { Percent of } 0 \\
\text { blocked verticatty }\end{array}$ \\
\hline Level I & $8 / 21 / 96$ & 0 & 0 \\
\hline $\begin{array}{l}\text { Level II } \\
\text { upstream. }\end{array}$ & \multicolumn{3}{|c|}{ Moderate. There is significant vegetation cover on the banks } \\
\hline
\end{tabular}

The upstream left bank protection, evident on $8 / 21 / 96$, partially blocks flows immediately Doscriho any foaturos noar ar at tho hridoo that mav, affort flow, (includo ahsorvation datol upstream of the bridge opening. 


\section{Description of the Geomorphic Setting}

General topography The channel is located in a moderate relief valley setting with a narrow, irregular flood plain, and steep valley walls on both sides.

Geomorphic conditions at bridge site: downstream (DS), upstream (US)

Date of inspection $\quad 8 / 21 / 96$

DS left: $\quad$ Moderately sloping channel bank to a narrow overbank

DS right: $\quad$ Moderately sloping channel bank to a narrow flood plain

US left: $\quad$ Steep channel bank and valley wall

US right: $\quad$ Moderately sloping channel bank to a narrow, irregular flood plain

\section{Description of the Channel}

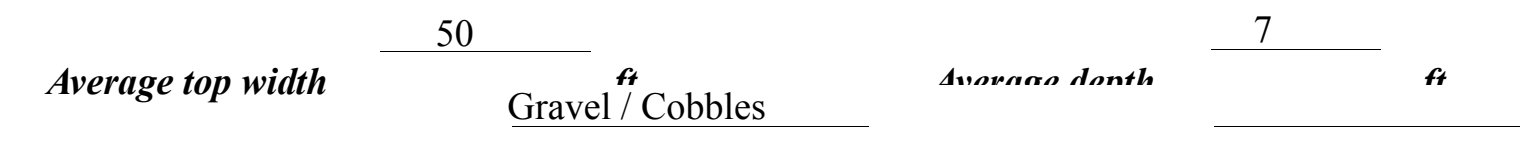

Predominant bed material

Bank material

Gravel / Boulders

Perennial and straight with semi-alluvial channel boundaries än irregular point and lateral bars.

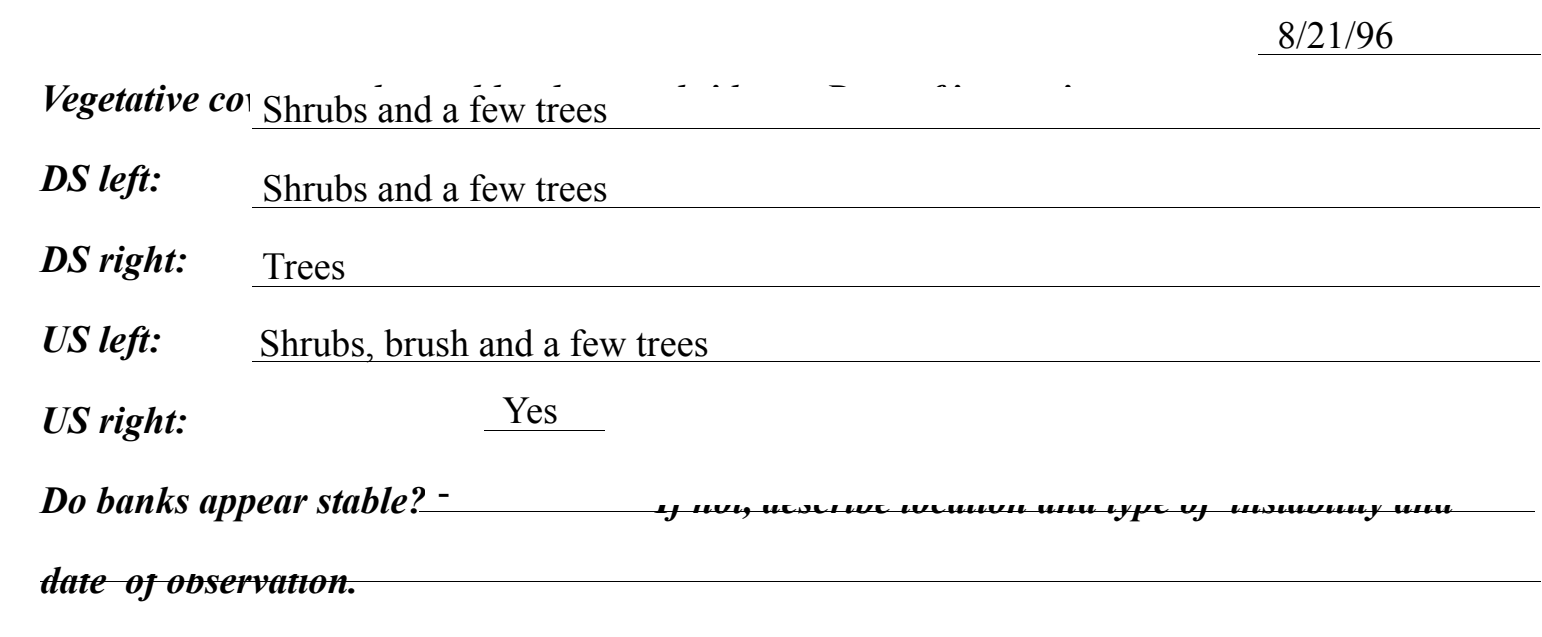

None were observed

on $8 / 21 / 96$.

Describe any obstructions in channel and date of observation. 


\title{
Hydrology
}

Drainage area $\frac{10.8}{\boldsymbol{m i}^{2}}$

Percentage of drainage area in physiographic provinces: (approximate)

Physiographic province/section New England / New England Upland
Percent of drainage area 100

\begin{abstract}
Is drainage area considered rural or urban?
Rural urbanization:

Describe any significant
\end{abstract}

Yes

Is there a USGS gage on the stream of interest? Saxtons River at Saxtons River, VT USGS gage description 01154000 (Discontinued)

USGS gage number 72.2

Gage drainage area $\quad \mathrm{mi}^{2}$ No

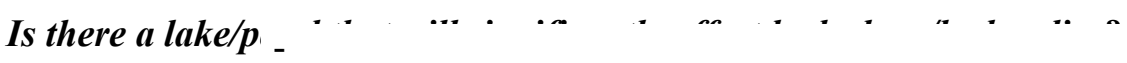

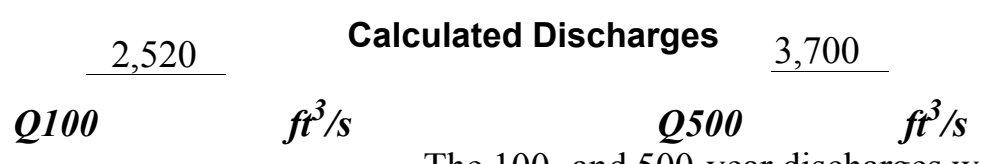

The 100- and 500-year discharges were selected

from flood frequency curve values ayailable for this site in the VTAOT database (VTAOT, written communication, May 1995). The VTAOT values were within a range defined by several flood frequency curves computed by use of empirical methods (Benson, 1962; FHWA, 1983; Johnson and Tasker, 1974; Potter, 1957a\&b; and Talbot, 1887). Each curve was extended graphically to the 500-year event. 


\section{Description of the Water-Surface Profile Model (WSPRO) Analysis}

Datum for WSPRO analysis (USGS survey, sea level, VTAOT plans)

USGS survey

Datum tie between USGS survey and VTAOT plans

Add 1.7 feet to the USGS

arbitrary survey datum to obtain the VTAOT plans' datum.

Description of reference marks used to determine USGS datum. $\quad$ RM1 is a metallic tablet

set in the left abutment concrete at the upstream end (elev. 499.05 feet, arbitrary survey datum).

$\mathrm{RM} 2$ is the center point of a chiseled " $\mathrm{X}$ " on top of the right abutment concrete at the

downstream end (elev. 499.93 feet, arbitrary survey datum).

\section{Cross-Sections Used in WSPRO Analysis}

\begin{tabular}{cccl}
\hline${ }^{1}$ Cross-section & $\begin{array}{c}\text { Section } \\
\text { Reference } \\
\text { Distance } \\
\text { (SRD) in feet }\end{array}$ & $\begin{array}{c}{ }^{2} \text { Cross-section } \\
\text { development }\end{array}$ & \multicolumn{1}{c}{ Comments } \\
\hline EXITX & -40 & 1 & Exit section \\
FULLV & 0 & 2 & $\begin{array}{l}\text { Downstream Full-valley section } \\
\text { (Templated from EXITX) }\end{array}$ \\
BRIDG & 0 & 1 & $\begin{array}{l}\text { Bridge section } \\
\text { Road Grade section }\end{array}$ \\
RDWAY & 22 & 1 & $\begin{array}{l}\text { Modelled Approach section } \\
\text { (Templated from APTEM) } \\
\text { APPRO }\end{array}$ \\
APTEM & 76 & 2 & $\begin{array}{l}\text { Approach section as surveyed } \\
\text { (Used as a template) }\end{array}$ \\
APPR2 & 103 & 1 & $\begin{array}{l}\text { Additional upstream section } \\
\text { (Templated from APTEM) }\end{array}$ \\
\hline
\end{tabular}

${ }^{1}$ For location of cross-sections see plan-view sketch included with Level I field form, Appendix E. For more detail on how cross-sections were developed see WSPRO input file. 


\section{Data and Assumptions Used in WSPRO Model}

Hydraulic analyses of the reach were done by use of the Federal Highway Administration's WSPRO step-backwater computer program (Shearman and others, 1986, and Shearman, 1990). The analyses reported herein reflect conditions existing at the site at the time of the study. Furthermore, in the development of the model it was necessary to assume no accumulation of debris or ice at the site. Also, flow was assumed to align with the abutments. Results of the hydraulic model are presented in the Bridge Hydraulic Summary, appendix B, and figure 7.

Channel roughness factors (Manning's "n”) used in the hydraulic model were estimated using field inspections at each cross section following the general guidelines described by Arcement and Schneider (1989). Final adjustments to the values were made during the modelling of the reach. Channel " $n$ " values for the reach ranged from 0.045 to 0.050 , and overbank " $n$ " values ranged from 0.035 to 0.050 .

Normal depth at the exit section (EXITX) was assumed as the starting water surface for the 100-year and incipient roadway-overtopping discharges. Critical depth was assumed as the starting water surface for the 500-year discharge. Normal depth was computed by use of the slope-conveyance method outlined in the user's manual for WSPRO (Shearman, 1990). The slope used was $0.0115 \mathrm{ft} / \mathrm{ft}$, which was estimated from the 100 -year water surface profile documented in the Flood Insurance Study for the Town of Grafton (FEMA, 1987). For the 500year event, the normal water surface was within 0.1 foot of the critical water surface. Therefore, the critical water surface was assumed to be a satisfactory starting water surface.

The surveyed approach section (APTEM) was moved along the approach channel slope $(0.0103 \mathrm{ft} / \mathrm{ft})$ to establish the modelled approach section (APPRO), one bridge length upstream of the upstream face as recommended by Shearman and others (1986). This location provides a consistent method for determining scour variables.

For the incipient-overtopping discharge, WSPRO assumes critical depth at the bridge section. A supercritical model was developed for this discharge. After analyzing both the supercritical and subcritical profiles, it was assumed that the water surface profile passes through critical depth within the bridge opening. Thus, the assumption of critical depth at the bridge is a satisfactory solution. 


\section{Bridge Hydraulics Summary}

$\begin{array}{llll}\text { Average bridge embankment elevation } & 500.1 & f t \\ \text { Average low steel elevation } & 498.4 & \boldsymbol{f t}\end{array}$

100-year discharge $\quad 2,520 \quad \mathrm{ft}^{3} / \mathrm{s}$

Water-surface elevation in bridge opening $\quad 498.4 \quad f t$

Road overtopping? ___ Yes Discharge over road __ $481 \quad \mathrm{ft}^{3} / \mathrm{s}$

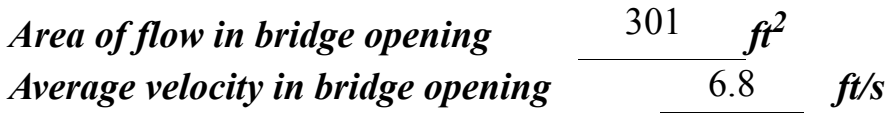

Maximum WSPRO tube velocity at bridge $\quad 12.2 \mathrm{ft} / \mathrm{s}$

Water-surface elevation at Approach section with bridge 499.4

Water-surface elevation at Approach section without bridge $\quad 495.7$

Amount of backwater caused by bridge

$3.7 \quad i$

500-year discharge $\quad 3,700 \quad \mathrm{ft}^{3} / \mathrm{s}$

Water-surface elevation in bridge opening

$498.6 f t$

Road overtopping? ___ Yes Discharge over road __ 1,310 $\boldsymbol{f t}^{3} / \mathbf{s}$

$\begin{array}{llll}\text { Area of flow in bridge opening } & 302 & \boldsymbol{f t}^{\mathbf{2}} & \\ \text { velocity in bridge opening } & & 7.9 \quad \mathrm{ft} / \mathrm{s}\end{array}$

Maximum WSPRO tube velocity at bridge 9.8 's

Water-surface elevation at Approach section with bridge

Water-surface elevation at Approach section without bridge

Amount of backwater caused by bridge

1.6

500.0

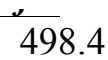

Incipient overtopping discharge $\quad 1,900 \quad \mathrm{ft}^{3} / \mathrm{s}$

Water-surface elevation in bridge opening $494.0 \quad t$

Area of flow in bridge opening $\quad 155 \quad \mathrm{ft}^{2}$

Average velocity in bridge opening $\quad 12.3 \quad \mathrm{ft} / \mathrm{s}$

Maximum WSPRO tube velocity at bridge $\quad 15.7 \mathrm{ft} / \mathrm{s}$

Water-surface elevation at Approach section with bridge

Water-surface elevation at Approach section without bridge

496.9

Amount of backwater caused by bridge $\quad 1.7_{\text {. }}^{\text {it }}$

495.2 


\section{Scour Analysis Summary}

\section{Special Conditions or Assumptions Made in Scour Analysis}

Scour depths were computed using the general guidelines described in Hydraulic Engineering Circular 18 (Richardson and Davis, 1995). Scour depths were calculated assuming an infinite depth of erosive material and a homogeneous particle-size distribution. The results of the scour analysis are presented in tables 1 and 2 and a graph of the scour depths is presented in figure 8 .

Contraction scour for the incipient roadway-overtopping discharge was computed by use of the clear-water contraction scour equation (Richardson and Davis, 1995, p. 32, equation 20). The 100-year and 500-year discharges resulted in orifice flow conditions at the bridge. Contraction scour at bridges with orifice flow is best estimated by use of the Chang pressure-flow scour equation (oral communication, J. Sterling Jones, October 4, 1996). Thus, contraction scour for the 100- and 500-year events were computed by use of the Chang equation (Richardson and Davis, 1995, p. 145-146). The computed streambed armoring depths suggest that armoring will not limit the depth of contraction scour.

For comparison, contraction scour for the discharges resulting in orifice flow also was computed by use of the Laursen clear-water contraction scour equation and the Umbrell pressure-flow equation (Richardson and Davis, 1995, p. 144). Furthermore, for the 100-and 500-year discharges, which resulted in unsubmerged orifice flow, contraction scour was computed by substituting estimates for the depth of flow at the downstream bridge face in the contraction scour equations. Results with respect to these alternative computations are provided in appendix $\mathrm{F}$.

Abutment scour was computed by use of the Froehlich equation (Richardson and Davis, 1995, p. 48, equation 28). Variables for the Froehlich equation include the Froude number of the flow approaching the embankments, the length of the embankment blocking flow, and the depth of flow approaching the embankment less any roadway overtopping. 


\section{Scour Results}

\section{0-yr discharge 500-yr discharge}

Contraction scour:

(Scour depths in feet)

Main channel

Live-bed scour

Clear-water scour

Depth to armoring

Left overbank

Right overbank

Local scour:

Abutment scour

Left abutment

9.7

10.9

8.2

12.6

14.2

5.7

Right abutment

Pier scour

Pier 1

Pier 2

Pier 3

\section{Abutments:}

Left abutment

Right abutment

Piers:

Pier 1

Pier 2

\section{Riprap Sizing}

Incipient overtopping 100-yr discharge 500-yrdischarge discharge

1.8

1.8

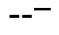

$--$

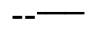
( $D_{50}$ in feet)

2.0

2.0

2.0

2.0
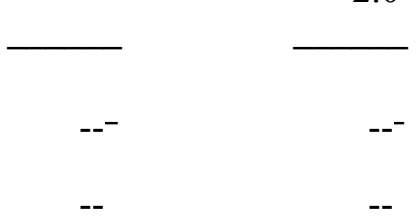

-- 


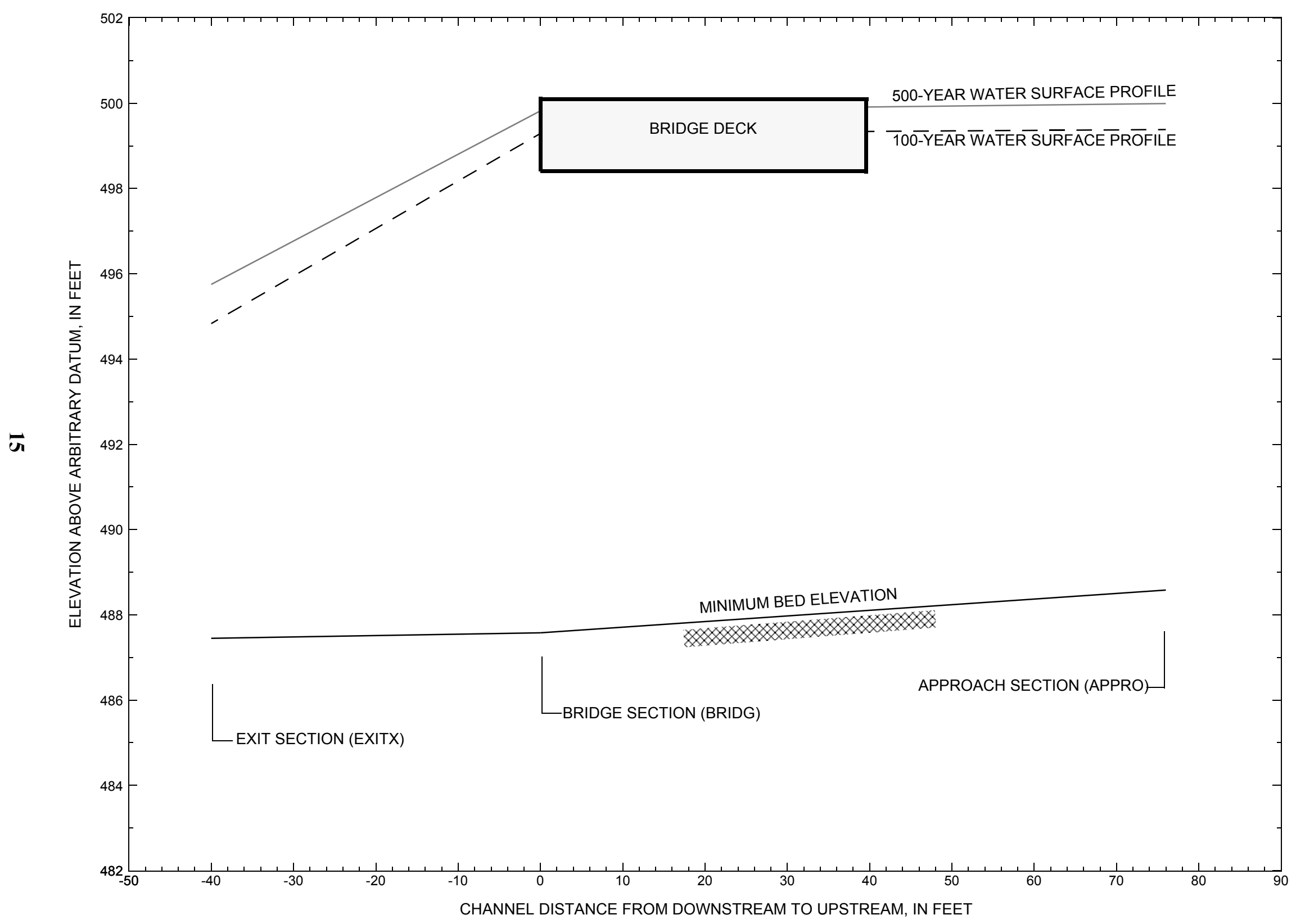

Figure 7. Water-surface profiles for the 100- and 500-year discharges at structure GRAFTH00020010 on Town Highway 2, crossing the Saxtons River, Grafton, Vermont. 


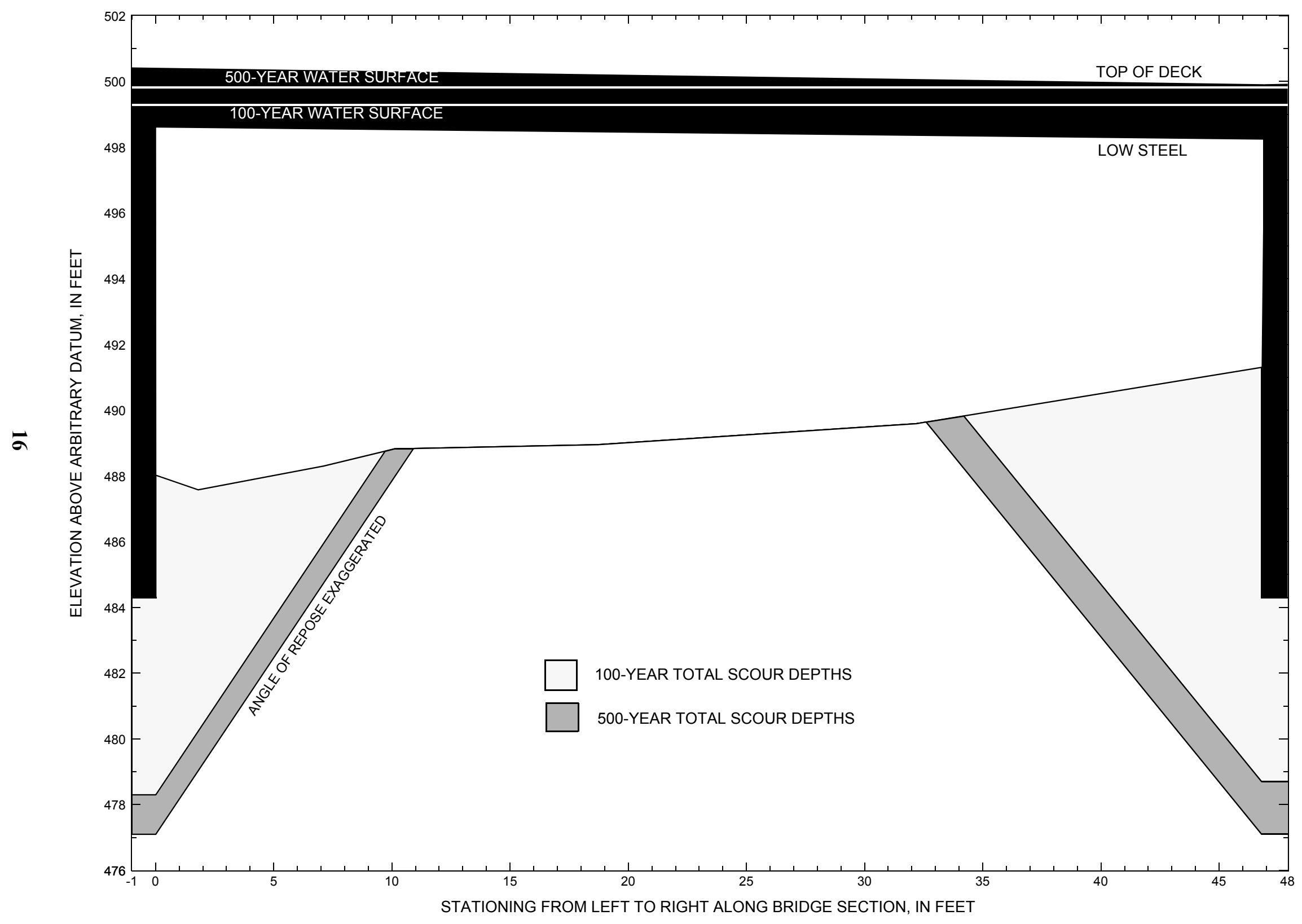

Figure 8. Scour elevations for the 100- and 500-year discharges at structure GRAFTH00020010 on Town Highway 2, crossing the Saxtons River, Grafton, Vermont. 
Table 1. Remaining footing/pile depth at abutments for the 100-year discharge at structure GRAFTH00020010 on Town Highway 2, crossing the Saxtons River, Grafton, Vermont.

[VTAOT, Vermont Agency of Transportation; --,no data]

\begin{tabular}{|c|c|c|c|c|c|c|c|c|c|c|c|}
\hline Description & Station $^{1}$ & $\begin{array}{l}\text { VTAOT } \\
\text { minimum } \\
\text { bridge seat } \\
\text { elevation } \\
\text { (feet) }\end{array}$ & $\begin{array}{l}\text { Surveyed } \\
\text { minimum } \\
\text { low-chord } \\
\text { elevation }{ }^{2} \\
\text { (feet) }\end{array}$ & $\begin{array}{c}\text { Bottom of } \\
\text { footing } \\
\text { elevation } \\
\text { (feet) }\end{array}$ & $\begin{array}{c}\text { Channel } \\
\text { elevation at } \\
\text { abutment/ } \\
\text { pier }^{2} \\
\text { (feet) }\end{array}$ & $\begin{array}{l}\text { Contraction } \\
\text { scour depth } \\
\text { (feet) }\end{array}$ & $\begin{array}{l}\text { Abutment } \\
\text { scour } \\
\text { depth } \\
\text { (feet) }\end{array}$ & $\begin{array}{l}\text { Pier } \\
\text { scour } \\
\text { depth } \\
\text { (feet) }\end{array}$ & $\begin{array}{l}\text { Depth of } \\
\text { total scour } \\
\text { (feet) }\end{array}$ & $\begin{array}{c}\text { Elevation of } \\
\text { scour }^{2} \\
\text { (feet) }\end{array}$ & $\begin{array}{c}\text { Remaining } \\
\text { footing/pile } \\
\text { depth } \\
\text { (feet) }\end{array}$ \\
\hline \multicolumn{12}{|c|}{100 -year discharge is 2,520 cubic-feet per second } \\
\hline Left abutment & 0.0 & 500.3 & 498.6 & 484.3 & 488.0 & 0.0 & 9.7 & -- & 9.7 & 478.3 & -6.0 \\
\hline Right abutment & 46.9 & 499.8 & 498.3 & 484.3 & 491.3 & 0.0 & 12.6 & -- & 12.6 & 478.7 & -5.6 \\
\hline
\end{tabular}

1.Measured along the face of the most constricting side of the bridge.

2.Arbitrary datum for this study.

Table 2. Remaining footing/pile depth at abutments for the 500-year discharge at structure GRAFTH00020010 on Town Highway 2, crossing the Saxtons River, Grafton, Vermont.

[VTAOT, Vermont Agency of Transportation; --, no data]

\begin{tabular}{|c|c|c|c|c|c|c|c|c|c|c|c|}
\hline Description & Station $^{1}$ & $\begin{array}{l}\text { VTAOT } \\
\text { minimum } \\
\text { bridge seat } \\
\text { elevation } \\
\text { (feet) }\end{array}$ & $\begin{array}{l}\text { Surveyed } \\
\text { minimum } \\
\text { low-chord } \\
\text { elevation }{ }^{2} \\
\text { (feet) }\end{array}$ & $\begin{array}{c}\text { Bottom of } \\
\text { footing } \\
\text { elevation } \\
\text { (feet) }\end{array}$ & $\begin{array}{c}\text { Channel } \\
\text { elevation at } \\
\text { abutment/ } \\
\text { pier }^{2} \\
\text { (feet) }\end{array}$ & $\begin{array}{l}\text { Contraction } \\
\text { scour depth } \\
\text { (feet) }\end{array}$ & $\begin{array}{c}\text { Abutment } \\
\text { scour } \\
\text { depth } \\
\text { (feet) }\end{array}$ & $\begin{array}{l}\text { Pier } \\
\text { scour } \\
\text { depth } \\
\text { (feet) }\end{array}$ & $\begin{array}{l}\text { Depth of } \\
\text { total scour } \\
\text { (feet) }\end{array}$ & $\begin{array}{c}\text { Elevation of } \\
\text { scour }^{2} \\
\text { (feet) }\end{array}$ & $\begin{array}{c}\text { Remaining } \\
\text { footing/pile } \\
\text { depth } \\
\text { (feet) }\end{array}$ \\
\hline \multicolumn{12}{|c|}{500 -year discharge is 3,700 cubic-feet per second } \\
\hline Left abutment & 0.0 & 500.3 & 498.6 & 484.3 & 488.0 & 0.0 & 10.9 & -- & 10.9 & 477.1 & -7.2 \\
\hline Right abutment & 46.9 & 499.8 & 498.3 & 484.3 & 491.3 & 0.0 & 14.2 & -- & 14.2 & 477.1 & -7.2 \\
\hline
\end{tabular}

1.Measured along the face of the most constricting side of the bridge.

2.Arbitrary datum for this study. 


\section{SELECTED REFERENCES}

Arcement, G.J., Jr., and Schneider, V.R., 1989, Guide for selecting Manning's roughness coefficients for natural channels and flood plains: U.S. Geological Survey Water-Supply Paper 2339, 38 p.

Barnes, H.H., Jr., 1967, Roughness characteristics of natural channels: U.S. Geological Survey Water-Supply Paper 1849,213 p.

Benson, M. A., 1962, Factors Influencing the Occurrence of Floods in a Humid Region of Diverse Terrain: U.S. Geological Survey WaterSupply Paper 1580-B, 64 p.

Brown, S.A. and Clyde, E.S., 1989, Design of riprap revetment: Federal Highway Administration Hydraulic Engineering Circular No. 11, Publication FHWA-IP-89-016, 156 p.

Federal Emergency Management Agency, 1987, Flood Insurance Study, Town of Grafton, Windham County, Vermont: Washington, D.C., August 1987.

Federal Highway Administration, 1983, Runoff estimates for small watersheds and development of sound design: Federal Highway Administration Report FHWA-RD-77-158

Federal Highway Administration, 1993, Stream Stability and Scour at Highway Bridges: Participant Workbook: Federal Highway Administration Report FHWA-HI-91-011.

Froehlich, D.C., 1989, Local scour at bridge abutments in Ports, M.A., ed., Hydraulic Engineering--Proceedings of the 1989 National Conference on Hydraulic Engineering: New York, American Society of Civil Engineers, p. 13-18.

Hayes, D.C.,1993, Site selection and collection of bridge-scour data in Delaware, Maryland, and Virginia: U.S. Geological Survey WaterResources Investigation Report 93-4017, 23 p.

Interagency Advisory Committee on Water Data, 1982, Guidelines for determining flood flow frequency: U.S. Geological Survey, Bulletin 17B of the Hydrology Subcommittee, 190 p.

Johnson, C.G. and Tasker, G.D.,1974, Progress report on flood magnitude and frequency of Vermont streams: U.S. Geological Survey OpenFile Report 74-130, 37 p.

Lagasse, P.F., Schall, J.D., Johnson, F., Richardson, E.V., Chang, F., 1995, Stream Stability at Highway Structures: Federal Highway Administration Hydraulic Engineering Circular No. 20, Publication FHWA-IP-90-014, 144 p.

Laursen, E.M., 1960, Scour at bridge crossings: Journal of the Hydraulics Division, American Society of Civil Engineers, v. 86, no. HY2, p. 39-53.

Potter, W. D., 1957a, Peak rates of runoff in the Adirondack, White Mountains, and Maine woods area, Bureau of Public Roads

Potter, W. D., 1957b, Peak rates of runoff in the New England Hill and Lowland area, Bureau of Public Roads

Richardson, E.V. and Davis, S.R., 1995, Evaluating scour at bridges: Federal Highway Administration Hydraulic Engineering Circular No. 18, Publication FHWA-IP-90-017, 204 p.

Richardson, E.V., Simons, D.B., and Julien, P.Y., 1990, Highways in the river environment: Federal Highway Administration Publication FHWA-HI-90-016.

Ritter, D.F., 1984, Process Geomorphology: W.C. Brown Co., Debuque, Iowa, 603 p.

Shearman, J.O., 1990, User's manual for WSPRO--a computer model for water surface profile computations: Federal Highway Administration Publication FHWA-IP-89-027, 187 p.

Shearman, J.O., Kirby, W.H., Schneider, V.R., and Flippo, H.N., 1986, Bridge waterways analysis model; research report: Federal Highway Administration Publication FHWA-RD-86-108, 112 p.

Talbot, A.N., 1887, The determination of water-way for bridges and culverts.

U.S. Geological Survey, 1984, Saxtons River, Vermont 7.5 by 15 Minute Series quadrangle map: U.S. Geological Survey Topographic Maps, Aerial photographs, 1977, Contour interval, 6 meters, Scale 1:25,000. 


\section{APPENDIX A: \\ WSPRO INPUT FILE}




\section{WSPRO INPUT FILE}

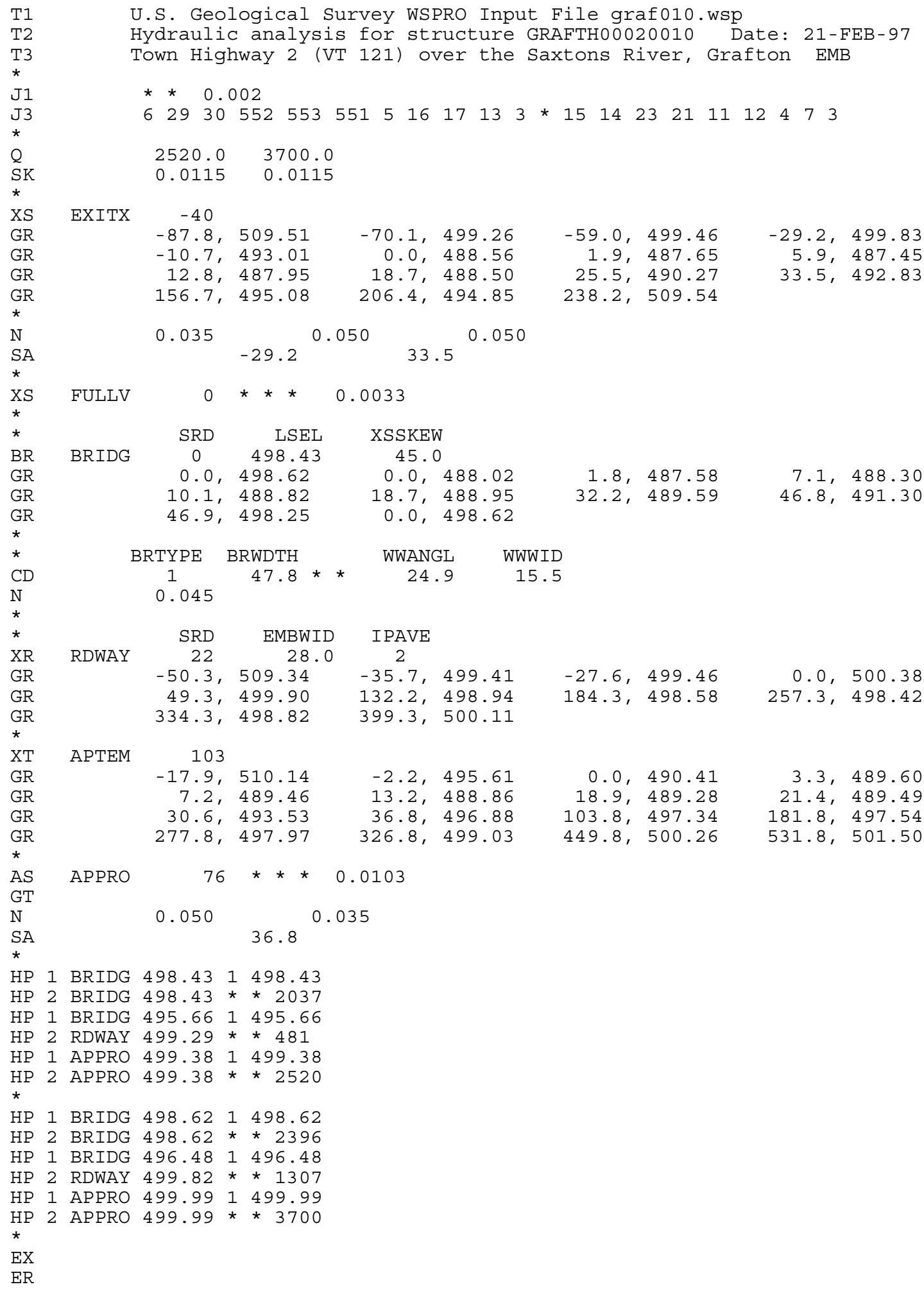




\section{WSPRO INPUT FILE (continued)}

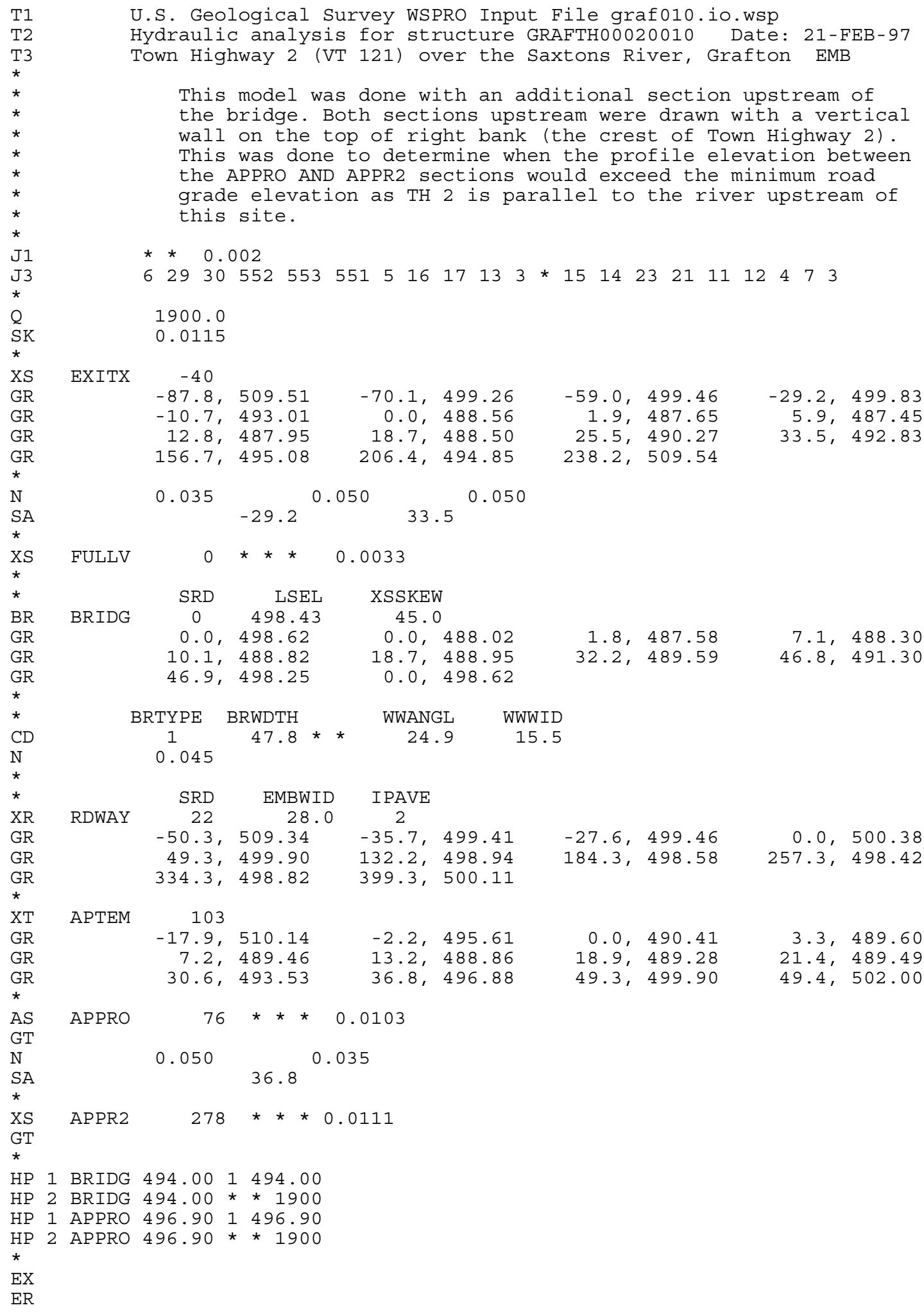




\section{APPENDIX B: \\ WSPRO OUTPUT FILE}




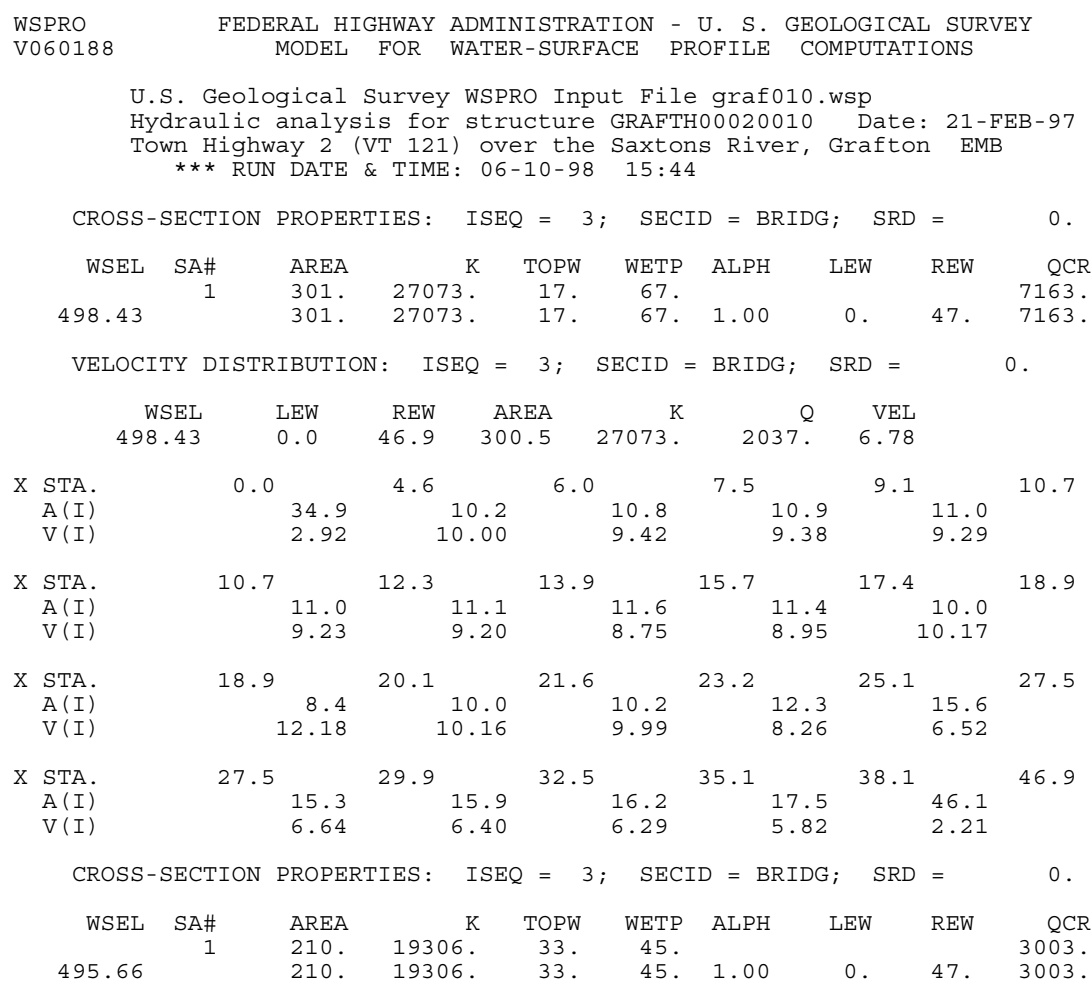

VELOCITY DISTRIBUTION: ISEQ $=4 ; \operatorname{SECID~}=$ RDWAY; $\quad \operatorname{SRD}=22$.

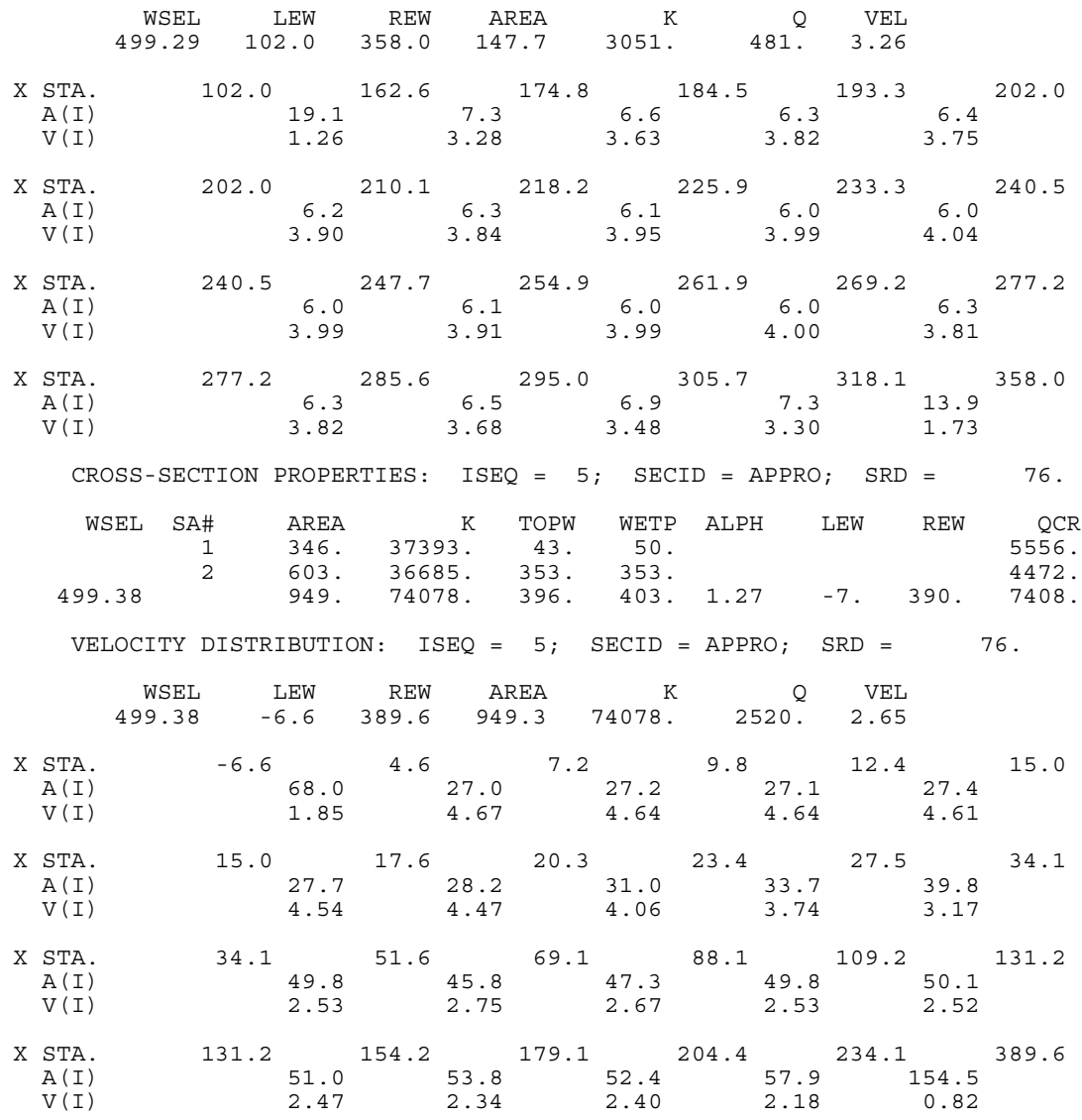




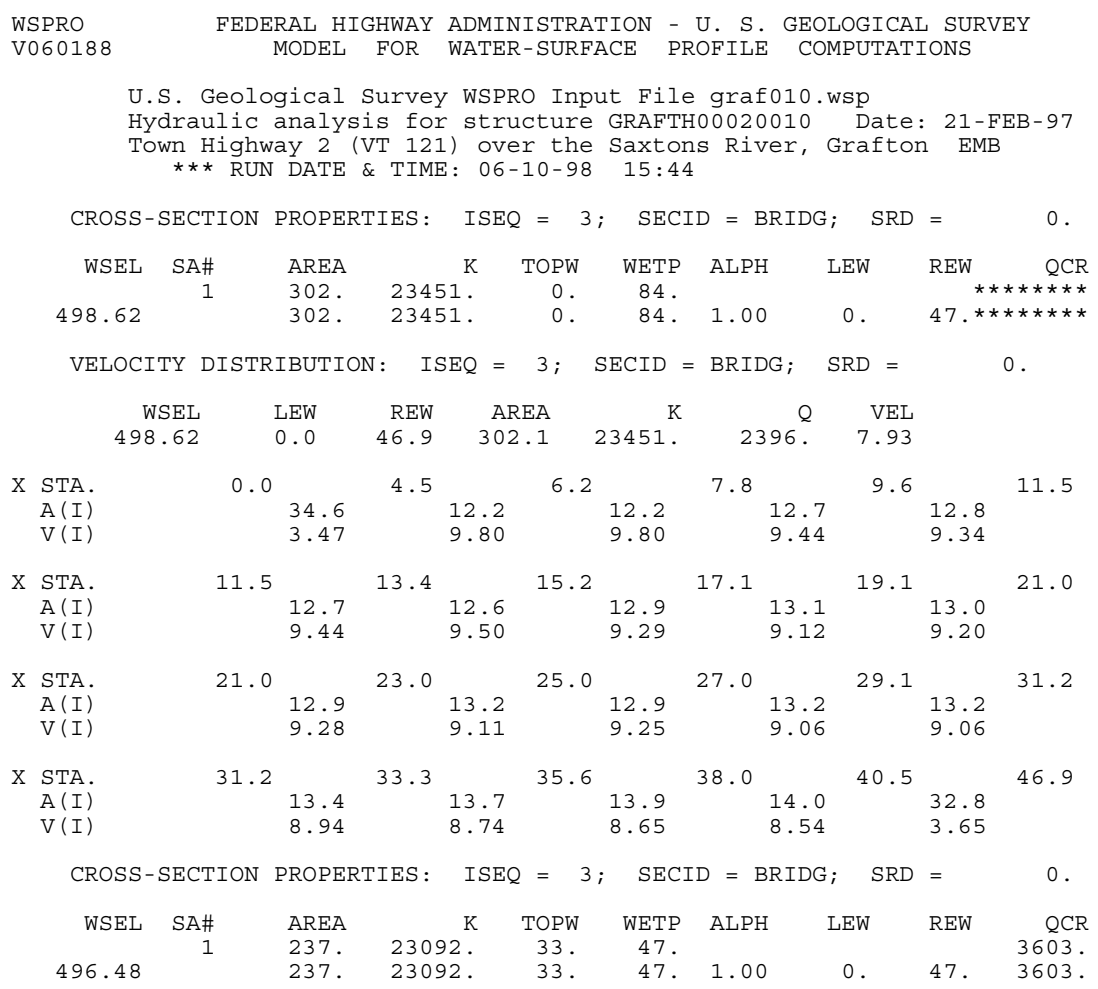

VELOCITY DISTRIBUTION: ISEQ $=4 ; \operatorname{SECID~=~RDWAY;~} \operatorname{SRD}=22$.

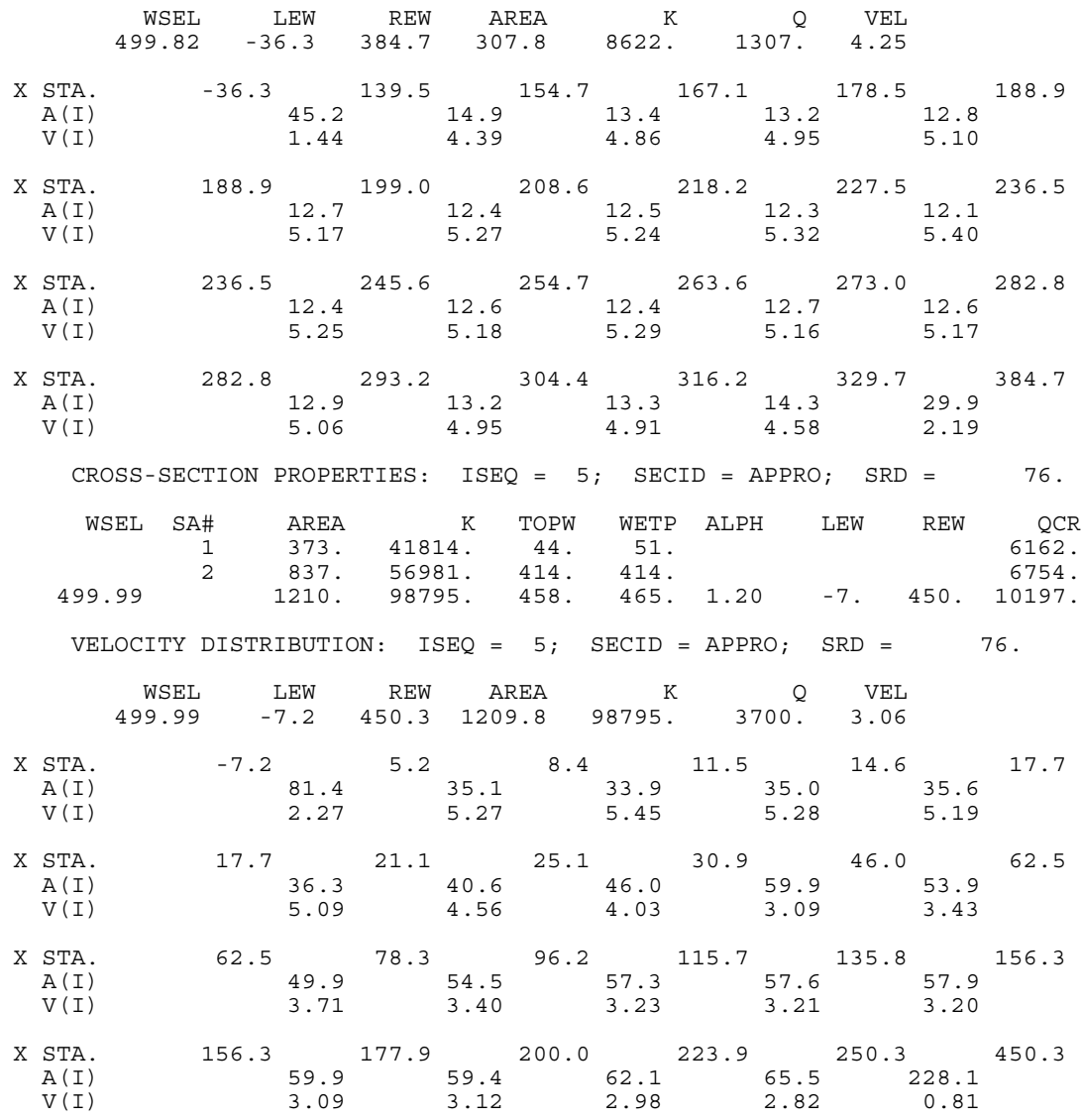


WSPRO OUTPUT FILE (continued)

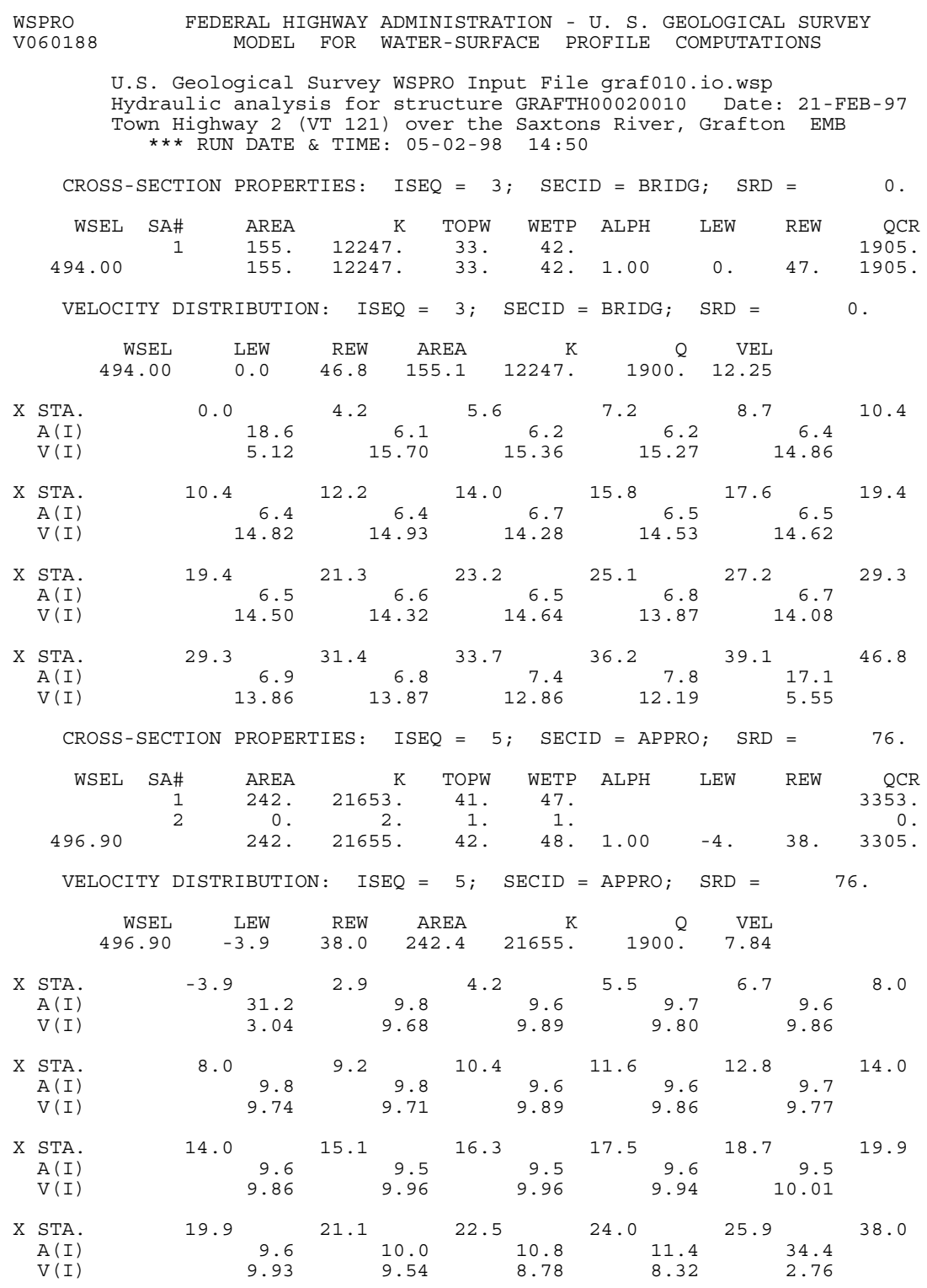


WSPRO OUTPUT FILE (continued)

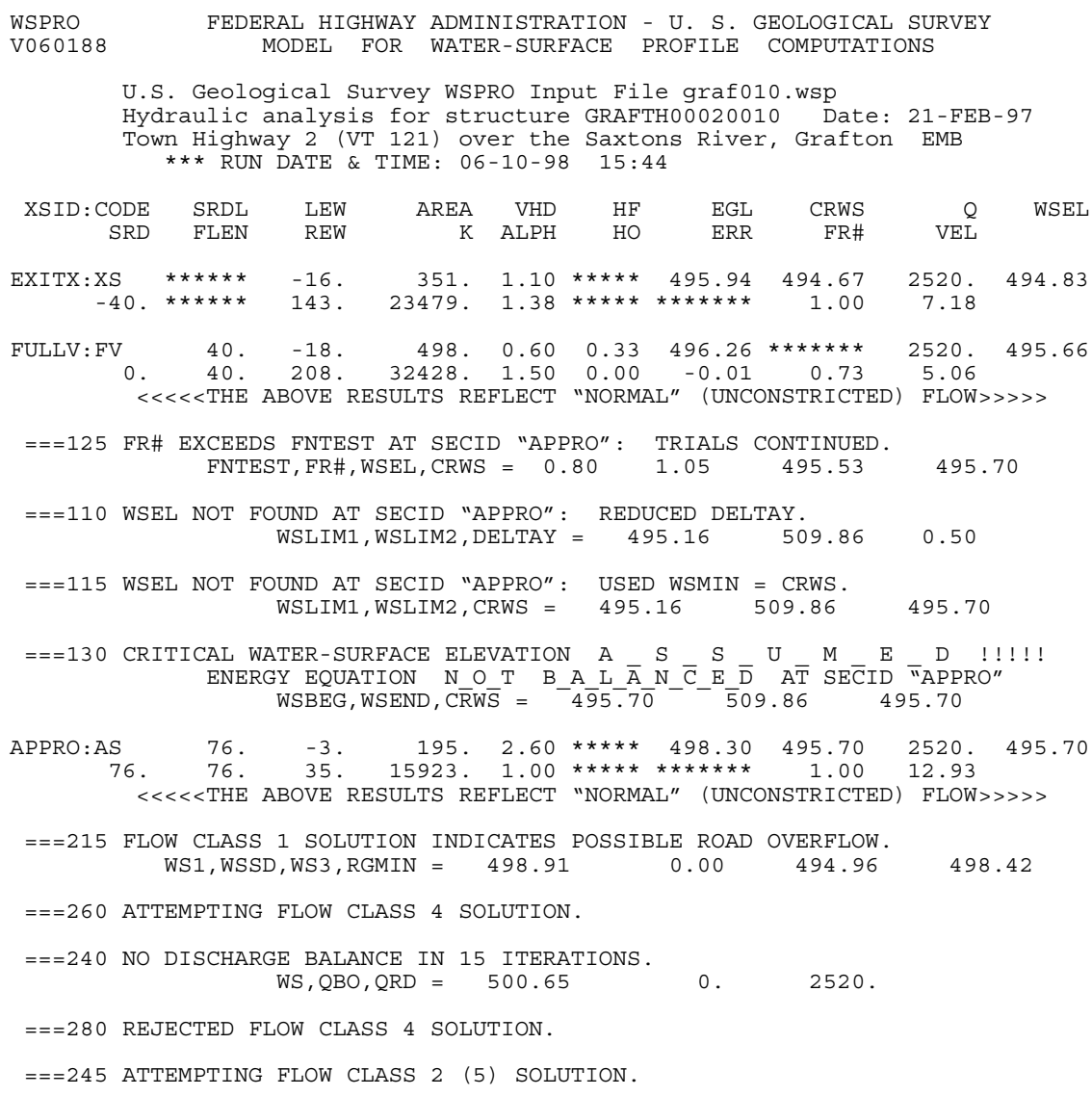




\section{WSPRO OUTPUT FILE (continued)}

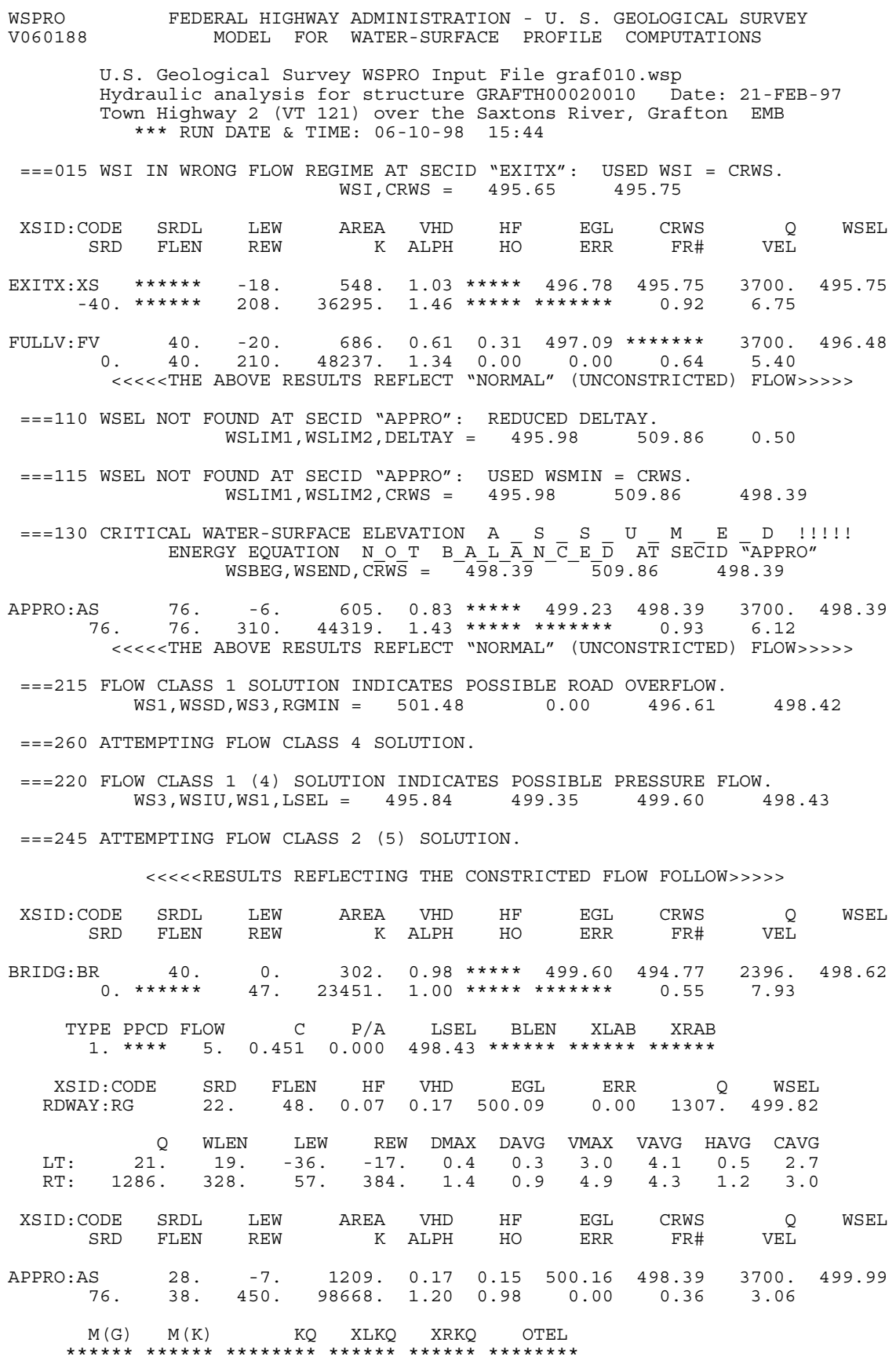

SECOND USER DEFINED TABLE.

\begin{tabular}{|c|c|c|c|c|c|c|c|c|c|}
\hline XSID : CODE & CRWS & FR\# & YMIN & YMAX & $\mathrm{HF}$ & $\mathrm{HO}$ & VHD & EGL & WSEL \\
\hline EXITX:XS & 495.75 & 0.92 & 487.45 & 509.54 * & $\star \star \star \star \star \star \star *$ & $* * * * *$ & 1.03 & 496.78 & 495.75 \\
\hline FULLV: FV & $\star \star \star \star \star \star \star \star \star *$ & 0.64 & 487.58 & 509.67 & 0.31 & 0.00 & 0.61 & 497.09 & 496.48 \\
\hline BRIDG : BR & 494.77 & 0.55 & 487.58 & 498.62 * & 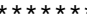 & $\star \star \star \star \star *$ & 0.98 & 499.60 & 498.62 \\
\hline RDWAY : RG & $\star \star \star \star \star \star * \star * \star * * * *$ & $\star * \star * *$ & 498.42 & 509.34 & $0.07 *$ & $\star \star \star \star * *$ & 0.17 & 500.09 & 499.82 \\
\hline APPRO : AS & 498.39 & 0.36 & 488.58 & 509.86 & 0.15 & 0.98 & 0.17 & 500.16 & 499.99 \\
\hline
\end{tabular}


WSPRO OUTPUT FILE (continued)

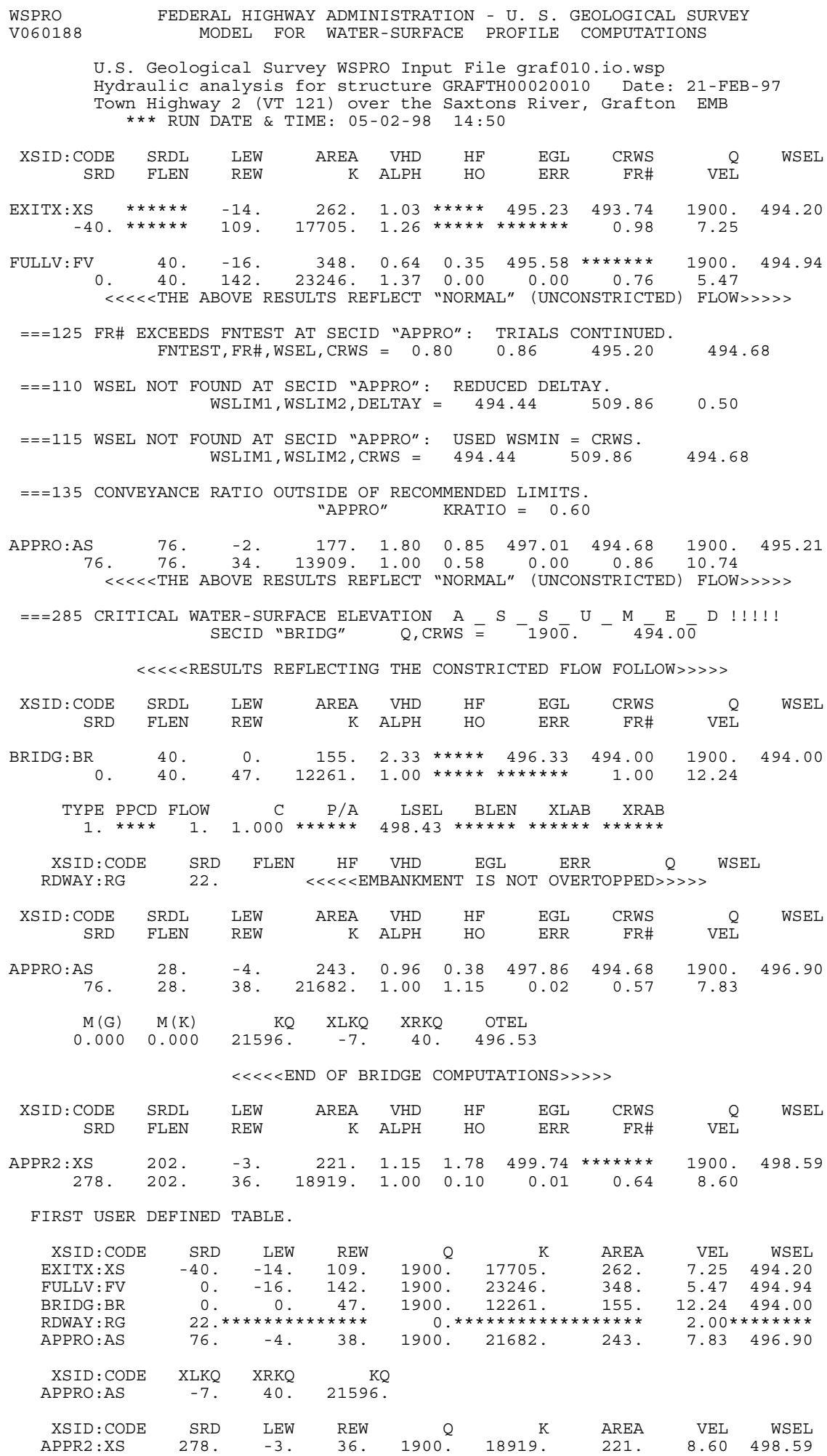

SECOND USER DEFINED TABLE.

\begin{tabular}{|c|c|c|c|c|c|c|c|c|c|}
\hline XSID : CODE & CRWS & FR\# & YMIN & YMAX & $\mathrm{HF}$ & $\mathrm{HO}$ & VHD & $\mathrm{EGL}$ & WSEL \\
\hline EXITX:XS & 493.74 & 0.98 & 487.45 & 509.54 * & $\star * \star * \star * \star *$ & $\star \star \star \star *$ & 1.03 & 495.23 & 494.20 \\
\hline FULLV : FV & $\star \star \star \star \star \star * \star *$ & 0.76 & 487.58 & 509.67 & 0.35 & 0.00 & 0.64 & 495.58 & 494.94 \\
\hline BRIDG : BR & 494.00 & 1.00 & 487.58 & $498.62 *$ & 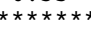 & $\star \star \star \star \star *$ & 2.33 & 496.33 & 494.00 \\
\hline RDWAY : RG & 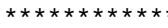 & $* \star * \star *$ & 498.42 & 509.34 * & $\star \star \star \star \star \star * \star *$ & $* \star \star * \star *$ & 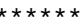 & 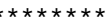 & $\star \star \star \star \star * \star * *$ \\
\hline APPRO: AS & 494.68 & 0.57 & 488.58 & 509.86 & 0.38 & 1.15 & 0.96 & 497.86 & 496.90 \\
\hline APPR2 : XS & $\star \star \star \star \star * \star \star \star *$ & 0.64 & 490.80 & 512.08 & 1.78 & 0.10 & 1.15 & 499.74 & 498.59 \\
\hline ER & & & & & & & & & \\
\hline IAL & OF & & & & & & & & \\
\hline
\end{tabular}




\section{APPENDIX C:}

\section{BED-MATERIAL PARTICLE-SIZE DISTRIBUTION}




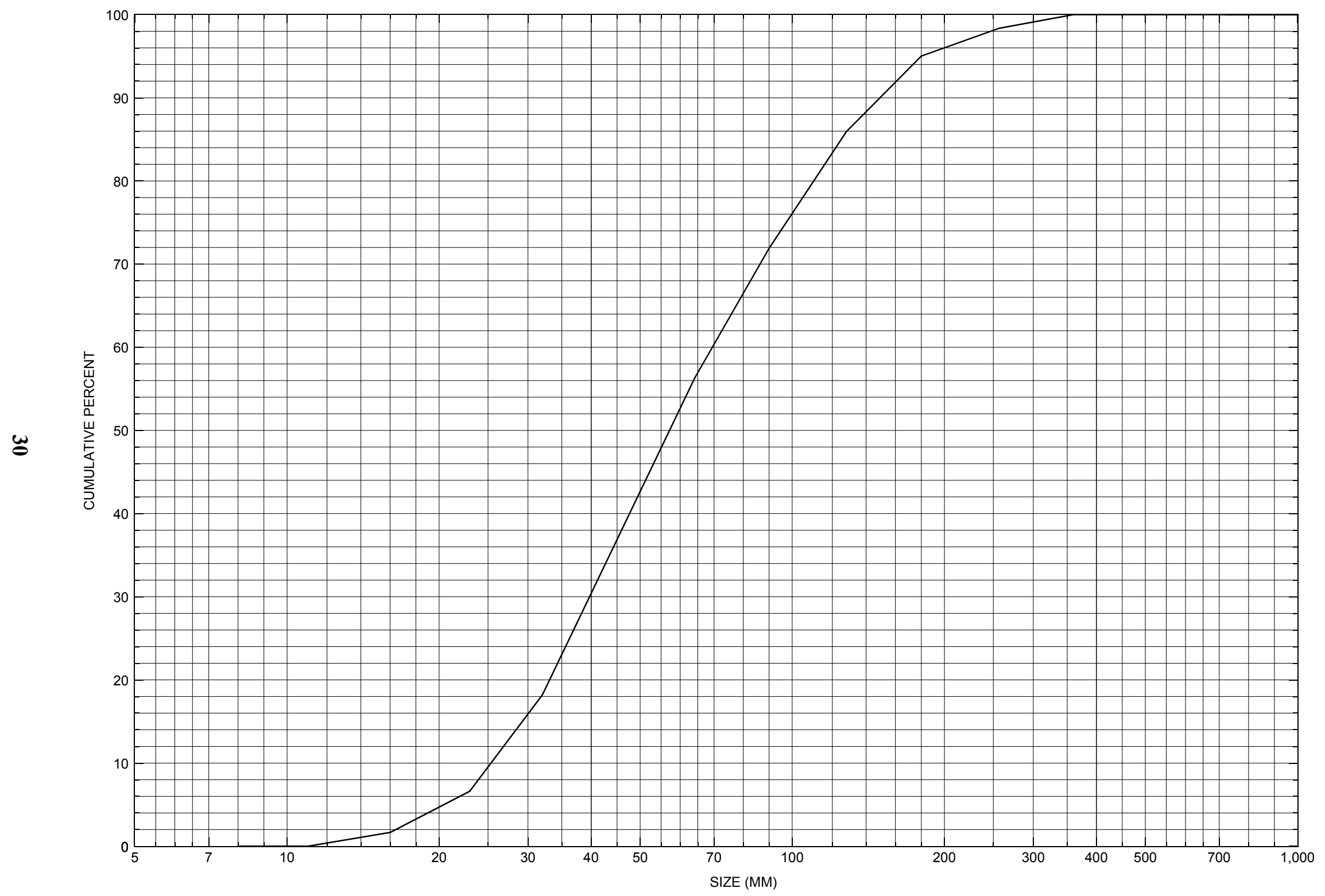

Appendix C. Bed material particle-size distribution for a pebble count in the channel approach of structure GRAFTH00020010, in Grafton, Vermont. 


\section{APPENDIX D: \\ HISTORICAL DATA FORM}




\section{Structure Number GRAFTH00020010}

\section{General Location Descriptive}

Data collected by (First Initial, Full last name) $\mathbf{E}$. BOEHMLER

Date $(M M / D D / Y Y) \_\mathbf{0 3} / \underline{29} / \underline{95}$

Highway District Number (I - 2; nn) $\mathbf{0 2}$

Town (FIPS place code; I - 4; nnnnn) $\mathbf{2 8 9 0 0}$

Waterway (I - 6) SAXTONS RIVER

Route Number TH002

Topographic Map Saxtons River

Latitude (I - 16; nnnn.n) $\mathbf{4 3 1 1 3}$
County (FIPS county code; I - 3; nnn)

Mile marker (I - 11; nnn.nnn) $\mathbf{0 0 4 2 4 0}$

Road Name (I - 7): -

Vicinity (I - 9) 8.3 MI E JCT VT 11

Hydrologic Unit Code: $\mathbf{0 1 0 8 0 1 0 7}$

Longitude (i - 17; nnnnn.n) $\mathbf{7 2 3 7 0}$

\section{Select Federal Inventory Codes}

FHWA Structure Number (I - 8) $\mathbf{2 0 0 1 2 6 0 0 1 0 1 3 0 6}$

Maintenance responsibility $(I-21 ; n n) \quad \mathbf{0 3}$

Year built (I - 27; YYYY) 1977

Average daily traffic, ADT (I - 29; nnnnnn) 001330

Year of ADT (I - 30; YY) $\mathbf{9 1}$

Opening skew to Roadway $(I-34 ; n n) \quad \mathbf{4 0}$

Operational status $(I-41 ; X) \quad \mathbf{A}$

Structure type (I- 43; nnn) $\mathbf{5 0 2}$

Approach span structure type $(I-44 ; n n n) \quad \mathbf{0 0 0}$

Number of spans (I - 45; nnn) $\underline{\mathbf{0 0 1}}$

Number of approach spans (I - 46; nnnn) $\mathbf{0 0 0 0}$

Comments:

The structural inspection report of 8/8/94 indicates this is a prestressed concrete slab type bridge. This bridge is part of the Federal Aid System and is listed under the route number FAS 126. The abutment walls and wingwalls are concrete. They are reported in "like-new" condition except for a few hairline vertical shrinkage cracks. The footings are reported as not in view at the surface. The waterway is noted as making a slight bend into the crossing. The streambed consists of stone and gravel. The banks are well protected with stone fill. There are no channel scour, bank erosion, or point bar / debris accumulation problems reported at this bridge site.
Maximum span length (I - 48; nnnn) $\underline{\mathbf{0 0 5 0}}$

Structure length (I - 49; nnnnnn) $\underline{000052}$

Deck Width (I - 52; nn.n) $\mathbf{2 8 0}$

Channel \& Protection $(I-61 ; n) \underline{7}$

Waterway adequacy $(I-71 ; n)$

Underwater Inspection Frequency $(I-92 B ; X Y Y) \_$N

Year Reconstructed (I - 106) $\mathbf{0 0 0 0}$

Clear span (nnn.n ft) _

Vertical clearance from streambed (nnn.n ft) $\underline{\mathbf{0 0 7 . 5}}$

Waterway of full opening $\left(n n n . n \mathrm{ft}^{2}\right)$ 


\section{Bridge Hydrologic Data}

Is there hydrologic data available? $\underline{\mathbf{N}}$ if No, type ctrl-n $h \quad$ VTAOT Drainage area $\left(m i^{2}\right)$ : -

Terrain character:

Stream character \& type: -

Streambed material:

Discharge Data (cfs):

$$
\mathrm{Q}_{2.33} \frac{-}{\mathbf{2 1 0 0}}
$$

$\mathrm{Q}_{10} \frac{\mathbf{1 3 0 0}}{\mathbf{2 5 2 0}}$

$$
\begin{aligned}
& Q_{25} \stackrel{1750}{-} \\
& Q_{500}-
\end{aligned}
$$

Record flood date $(M M / D D / Y Y)$ :

Water surface elevation (ft): 6.1

Estimated Discharge (cfs): $1 \mathbf{1 7 5 0}$ Velocity at Q 25 (ft/s): $\mathbf{7 . 8}$

Ice conditions (Heavy, Moderate, Light) : -

Debris (Heavy, Moderate, Light):

The stage increases to maximum highwater elevation (Rapidly, Not rapidly):

The stream response is (Flashy, Not flashy):

Describe any significant site conditions upstream or downstream that may influence the stream's stage: -

Watershed storage area (in percent):

The watershed storage area is: - _ (1-mainly at the headwaters; 2- uniformly distributed; 3-immediatly upstream oi the site)

Water Surface Elevation Estimates for Existing Structure:

\begin{tabular}{|l|l|l|l|l|l|}
\hline Peak discharge frequency & $Q_{2.33}$ & $Q_{10}$ & $Q_{25}$ & $Q_{50}$ & $Q_{100}$ \\
Water surface elevation (ft)) & - & $\mathbf{5 . 2}$ & $\mathbf{6 . 3}$ & $\mathbf{7 . 2}$ & $\mathbf{8 . 1}$ \\
Velocity $(\mathrm{ft} / \mathrm{sec})$ & - & - & $\mathbf{7 . 8}$ & - & - \\
\hline
\end{tabular}

Long term stream bed changes: -

Is the roadway overtopped below the $\mathrm{Q}_{100}$ ? (Yes, No, Unknown): $\mathbf{U} \quad$ Frequency: Relief Elevation (ft): Discharge over roadway at $Q_{100}\left(f t^{3} / \mathrm{sec}\right)$ :

Are there other structures nearby? (Yes, No, Unknown): Upstream distance (miles): Town: If No or Unknown, type ctrl-n os Highway No. :Structure No. : Year Built:

Clear span (ft): Clear Height (ft): Full Waterway $\left(f t^{2}\right)$ : 
Downstream distance (miles): Town: Year Built:

Highway No. : Structure No. : Structure Type:

Clear span $(f t):$ Clear Height $(f t)$ : Full Waterway $\left(f t^{2}\right)$ :

Comments:

The structures records indicate a hydraulic report was generated for this site, but there was no folder found in the hydraulics section for this site.

\section{USGS Watershed Data}

Watershed Hydrographic Data

Drainage area $(D A) \underline{10.79} \mathrm{mi}^{2}$ Lake and pond area $\mathbf{0 . 0 6}$ $\mathrm{mi}^{2}$

Watershed storage (ST) 0.5

Bridge site elevation 942 $\mathrm{ft}$ $\%$

Main channel length 7.85 $\mathrm{mi}$ $10 \%$ channel length elevation 1083 $\mathrm{ft} \quad 85 \%$ channel length elevation $\mathrm{ft}$

Main channel slope $(S)$

(S) 127.04 $\mathrm{ft} / \mathrm{mi}$

Watershed Precipitation Data

Average site precipitation in Average headwater precipitation in

Maximum 2yr-24hr precipitation event $(124,2)$ in

Average seasonal snowfall (Sn) $\mathrm{ft}$ 


\section{Bridge Plan Data}

Are plans available? $\mathbf{Y}$ If no, type ctrl-n pl Date issued for construction (MM/YYYY): $\mathbf{1 0} / \mathbf{1 9 7 6}$ Project Number ER 35(6) (DR-2-60)

Minimum channel bed elevation: $\mathbf{4 9 0 . 5}$

Low superstructure elevation: USLAB $\underline{\mathbf{4 9 8 . 9 1}}$ DSLAB $\underline{\mathbf{5 0 0 . 2 8}}$ USRAB $\underline{\mathbf{4 9 8 . 4 6}}$ DSRAB $\underline{\mathbf{4 9 9 . 8 2}}$

Benchmark location description:

BM\#2 is a spike in the root of an 18 inch maple tree, elevation 494.91. The tree is located 100 feet behind the downstream end of the left abutment and 100 feet from the center line of the roadway to the right bank of the river.

Reference Point (MSL, Arbitrary, Other): Arbitrary $\quad$ Datum (NAD27, NAD83, Other): Arbitrary Foundation Type: 1 (1-Spreadfooting; 2-Pile; 3- Gravity; 4-Unknown)

If 1: Footing Thickness $\mathbf{2 . 0} \quad$ Footing bottom elevation: $\underline{\mathbf{4 8 6 . 0}}$

If 2: Pile Type: ___ (1-Wood; 2-Steel or metal; 3-Concrete) Approximate pile driven length: -

If 3: Footing bottom elevation: -

Is boring information available? $\mathbf{N}$ If no, type ctrl-n bi Number of borings taken: _-

Foundation Material Type: $\mathbf{3}$ (1-regolith, 2-bedrock, 3-unknown)

Briefly describe material at foundation bottom elevation or around piles:

NO FOUNDATION MATERIAL INFORMATION

Comments:

There are no other points on the bridge with elevation data available. 


\section{Cross-sectional Data}

Is cross-sectional data available? $\underline{\mathbf{Y}}$ If no, type ctrl-n xs

Source (FEMA, VTAOT, Other)? VTAOT

Comments: Several cross sections are printed and kept with the plans and may be retrieved when needed. There were reproducible bridge cross sections.

\begin{tabular}{|l|l|l|l|l|l|l|l|l|l|l|l|}
\hline Station & - & - & - & - & - & - & - & - & - & - & - \\
\hline Feature & - & - & - & - & - & - & - & - & - & - & - \\
\hline $\begin{array}{l}\text { Low cord } \\
\text { elevation }\end{array}$ & - & - & - & - & - & - & - & - & - & - & - \\
\hline $\begin{array}{l}\text { Bed } \\
\text { elevation }\end{array}$ & - & - & - & - & - & - & - & - & - & - & - \\
\hline $\begin{array}{l}\text { Low cord to } \\
\text { bed length }\end{array}$ & - & - & - & - & - & - & - & - & - & - & - \\
\hline Station & - & - & - & - & - & - & - & - & - & - & - \\
\hline Feature & - & - & - & - & - & - & - & - & - & - & - \\
\hline $\begin{array}{l}\text { Low cord } \\
\text { elevation }\end{array}$ & - & - & - & - & - & - & - & - & - & - & - \\
\hline $\begin{array}{l}\text { Bed } \\
\text { elevation }\end{array}$ & - & - & - & - & - & - & - & - & - & - & - \\
\hline $\begin{array}{l}\text { Low cord to } \\
\text { bed length }\end{array}$ & - & - & - & - & - & - & - & - & - & - & - \\
\hline
\end{tabular}

Source (FEMA, VTAOT, Other)?

Comments: -

\begin{tabular}{|l|l|l|l|l|l|l|l|l|l|l|l|}
\hline Station & - & - & - & - & - & - & - & - & - & - & - \\
\hline Feature & - & - & - & - & - & - & - & - & - & - & - \\
\hline $\begin{array}{l}\text { Low cord } \\
\text { elevation }\end{array}$ & - & - & - & - & - & - & - & - & - & - & - \\
\hline $\begin{array}{l}\text { Bed } \\
\text { elevation }\end{array}$ & - & - & - & - & - & - & - & - & - & - & - \\
\hline $\begin{array}{l}\text { Low cord to } \\
\text { bed length }\end{array}$ & - & - & - & - & - & - & - & - & - & - & - \\
\hline Station & - & - & - & - & - & - & - & - & - & - & - \\
\hline Feature & - & - & - & - & - & - & - & - & - & - & - \\
\hline $\begin{array}{l}\text { Low cord } \\
\text { elevation }\end{array}$ & - & - & - & - & - & - & - & - & - & - & - \\
\hline $\begin{array}{l}\text { Bed } \\
\text { elevation }\end{array}$ & - & - & - & - & - & - & - & - & - & - & - \\
\hline $\begin{array}{l}\text { Low cord to } \\
\text { bed length }\end{array}$ & - & - & - & - & - & - & - & - & - & - & - \\
\hline
\end{tabular}




\section{APPENDIX E: \\ LEVEL I DATA FORM}


U. S. Geological Survey

Bridge Field Data Collection and Processing Form

Qa/Qc Check by: EW

Date: $9 / 26 / 96$

Computerized by: $\mathbf{E W}$ Date: $9 / 26 / 96$

Structure Number GRAFTH00020010

Reviewd by: $\quad$ EMB Date: $\underline{3 / 17 / 97}$

\section{A. General Location Descriptive}

1. Data collected by (First Initial, Full last name) $\underline{\text { R. HAMMOND }}$

Date $(M M / D D / Y Y) \underline{08} / \underline{\mathbf{2 1} / 1996}$

2. Highway District Number $\mathbf{0 2}$

Mile marker 004240

County Windham (025)

Town Grafton (28900)

Waterway (I - 6) Saxtons River

Road Name Houghtonville Road

Route Number TH 2

Hydrologic Unit Code: $\mathbf{0 1 0 8 0 1 0 7}$

3. Descriptive comments:

This bridge is located 8.3 miles east of the intersection with VT 121 in Grafton and approximately 1.0 mile northwest from the intersection with Main Street.

\section{B. Bridge Deck Observations}
4. Surface cover... LBUS 6
RBUS 2
LBDS 3
RBDS 3
Overall $\mathbf{3}$

(2b us,ds,lb,rb: 1- Urban; 2- Suburban; 3- Row crops; 4- Pasture; 5- Shrub- and brushland; 6- Forest; 7- Wetland)
5. Ambient water surface... US $\underline{2}$
UB 1
DS 1
(1- pool; 2- riffle)

6. Bridge structure type 1 (1- single span; 2- multiple span; 3- single arch; 4- multiple arch; 5-cylindrical culvert; 6- box culvert; or 7-other)
7. Bridge length $\mathbf{5 2}$ (feet)
Span length $\mathbf{5 0}$
(feet)
Bridge width 28 (feet)

\section{Road approach to bridge:}
8. LB 0
RB 0
( 0 even, 1- lower, 2- higher)
9. LB 2 RB 2
(1- Paved, 2- Not paved)

10. Embankment slope (run / rise in feet / foot):

US left

US right

\begin{tabular}{|c|c|c|c|}
\hline \multicolumn{2}{|c|}{ Protection } & \multirow{2}{*}{ 13.Erosion } & 14.Severity \\
\hline 11.Type & 12.Cond. & - & $\underline{\mathbf{0}}$ \\
\hline $\mathbf{2}$ & $\mathbf{1}$ & $\mathbf{2}$ & $\mathbf{-}$ \\
\hline $\mathbf{2}$ & $\mathbf{1}$ & $\mathbf{0}$ & - \\
\hline $\mathbf{0}$ & - & $\mathbf{2}$ & $\mathbf{0}$ \\
\hline $\mathbf{0}$ & - & $\mathbf{0}$ & - \\
\hline
\end{tabular}

Bank protection types: 0- none; 1- < 12 inches;

2- < 36 inches; 3- < 48 inches;

4- $<60$ inches; 5- wall / artificial levee

Bank protection conditions: 1- good; 2- slumped;

3- eroded; 4- failed

Erosion: 0 - none; 1- channel erosion; 2-

road wash; 3- both; 4- other

Erosion Severity: 0 - none; 1- slight; 2- moderate;

\section{Channel approach to bridge (BF):}

15. Angle of approach: $\mathbf{2 0}$

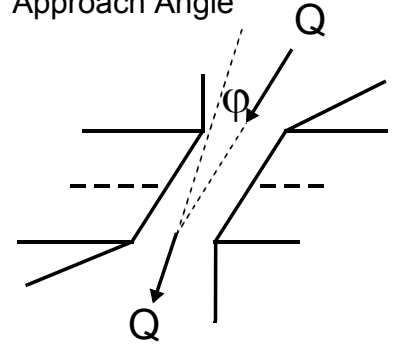

17. Channel impact zone 1:

Where? LB (LB, RB)

Range? 37 feet US

Channel impact zone 2:

Where? $(L B, R B)$

Range? feet (US, UB, DS) to feet

16. Bridge skew: 60 Bridge Skew Angle

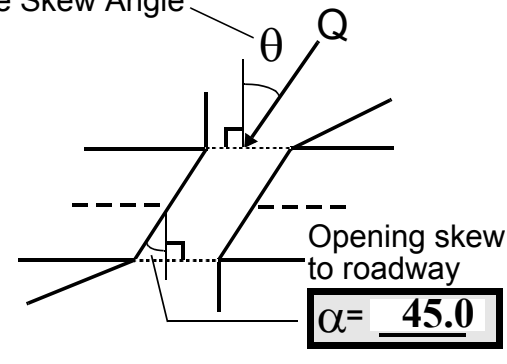

\section{Exist? $\mathbf{Y}(Y$ or $N)$}

Severity 1

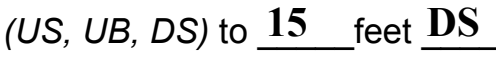

Exist? $\underline{\mathbf{N}}(\mathrm{Y}$ or $N)$

Severity

Impact Severity: 0- none to very slight; 1- Slight; 2- Moderate; 3- Severe 
18. Bridge Type: 1a

1a- Vertical abutments with wingwalls

1 b- Vertical abutments without wingwalls

2- Vertical abutments and wingwalls, sloping embankment Wingwalls perpendicular to abut. face

3- Spill through abutments

4- Sloping embankment, vertical wingwalls and abutments

Wingwall angle less than $90^{\circ}$.

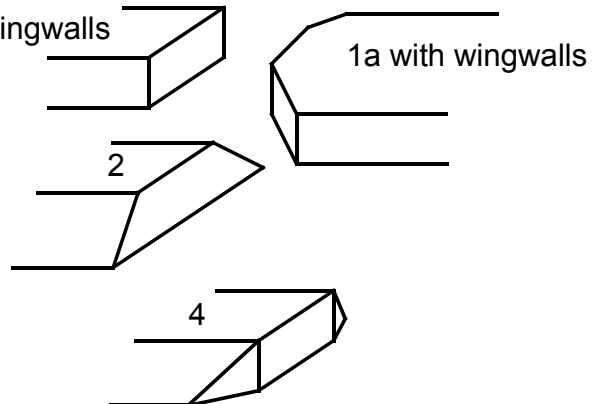

19. Bridge Deck Comments (surface cover variations, measured bridge and span lengths, bridge type variations, approach overflow width, etc.)

\#4 Surface cover on the right bank upstream consists of brush and woods along the stream and the TH2 roadway surface on the overbank. A house, a couple of barns, a store, and rows of raspberry and blueberry bushes make up the surface cover on the right bank downstream. The surface cover on the left bank downstream is a field of Christmas trees.

\#7: The measured bridge length, upstream and downstream span lengths, and the bridge width were 52.2 feet, 48.6 feet, 48.1 feet and 28.1 feet respectively.

\#11: The upstream right bank protection extends up to the road level.

\section{Upstream Channel Assessment}

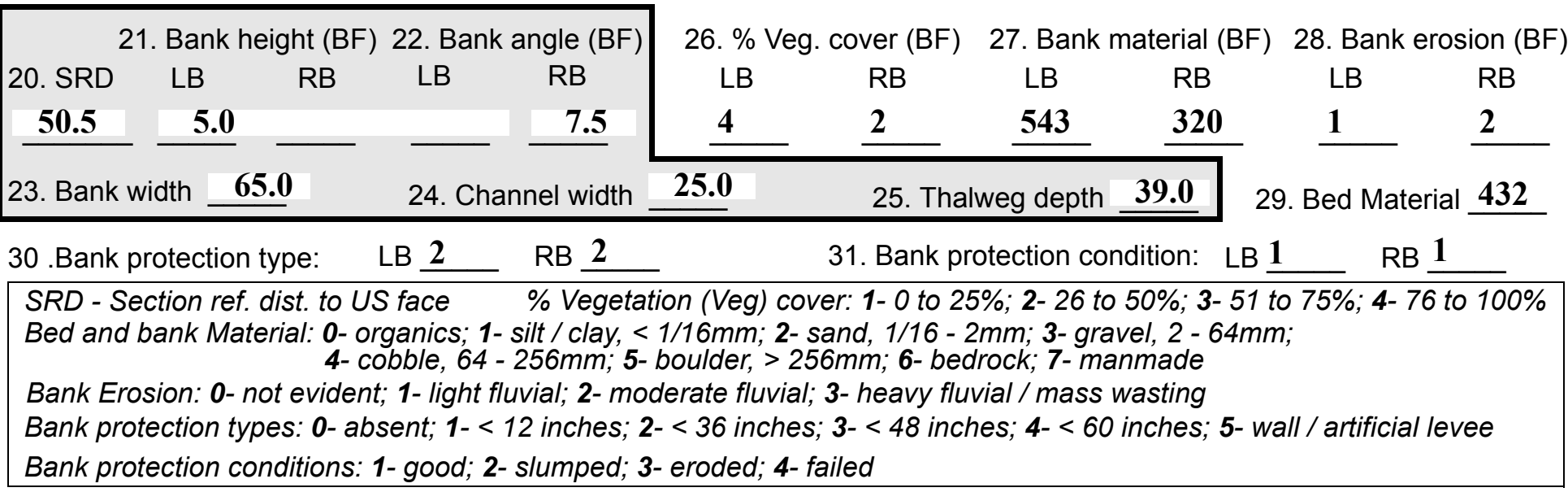

32. Comments (bank material variation, minor inflows, protection extent, etc.):

\#28: Right bank cut-bank is located upstream of protection.

\#30: Left bank protection extends from 37 feet upstream to 11 feet under bridge. It protects the wingwall from the bed to halfway up the wingwall.

Right bank protection extends from 30 feet upstream to 90 feet upstream. 

feet US (US, UB) to $\mathbf{3 0}$ feet $\underline{\mathbf{D S}}$ (US, UB, DS) positioned 15 \%LB to $100 \% R B$

37. Material: $\mathbf{3 4 2}$

38. Point or side bar comments (Circle Point or Side; Note additional bars, material variation, status, etc.):

Additional point bar extends from approximately 200 feet upstream to 55 feet upstream. It is positioned $0 \%$ LB to $50 \%$ RB. It is 20 feet wide at 158 feet upstream. This bar is covered by grass with some small woody plants at the upstream end.

39. Is a cut-bank present? $\mathbf{Y}$ (Y or if $N$ type ctrl-n cb) 40. Where? RB (LB or RB)

41. Mid-bank distance: 140 42. Cut bank extent: $\underline{\mathbf{2 0 0}}$ feet $\underline{\mathrm{US}}$ (US, UB) to $\underline{\mathbf{9 0}}$ feet $\underline{\mathbf{U S}}$ (US, UB, DS)

43. Bank damage: 1 (1- eroded and/or creep; 2- slip failure; 3- block failure)

44. Cut bank comments (eg. additional cut banks, protection condition, etc.):

Tree roots are undercut and exposed from 150 feet upstream to 120 feet upstream. Undercutting is most severe at 140 feet upstream.

\section{Is channel scour present? $\mathbf{Y}$ ( $Y$ or if $N$ type ctrl-n cs)}

47. Scour dimensions: Length $\mathbf{5 1}$ Width 6 Depth : $\mathbf{1 . 0}$

46. Mid-scour distance: $\underline{\mathbf{0}}$

48. Scour comments (eg. additional scour areas, local scouring process, etc.):

Average thalweg ranges from 0.3 to 0.5 feet (i.e. riffle to pool). The maximum scour depth is 1.5 feet.

The scour is along the edge of the left bank protection and the upstream end of the left abutment wall.

49. Are there major confluences? $\mathbf{N}$ ( $Y$ or if $N$ type ctrl-n $m c)$

51. Confluence 1: Distance Confluence 2: Distance 52. Enters on Enters on ( $L B$ or $R B)$ (LB or $R B)$

54. Confluence comments (eg. confluence name):

NO MAJOR CONFLUENCES
50. How many? -

53. Type(1-perennial; 2- ephemeral)

Type (1-perennial; 2- ephemeral)

\section{Under Bridge Channel Assessment}

55. Channel restraint (BF)? LB 2

\begin{tabular}{|ccccc}
\hline \multicolumn{2}{|c}{ 56. Height (BF) } & \multicolumn{2}{c}{57 Angle (BF) } \\
LB & RB & LB & RB \\
$\mathbf{2 1 . 5}$ & & & $\mathbf{0 . 5}$ & \\
\hline
\end{tabular}
(1- natural bank; 2- abutment; 3- artificial levee)

58. Bank width (BF) 59. Channel width (Amb) -

61. Material (BF)

LB RB

$2 \quad 7$
62. Erosion (BF)

LB RB

7

63. Bed Material -

Bed and bank Material: 0- organics; 1- silt / clay, < 1/16mm; 2- sand, 1/16 - 2mm; 3- gravel, 2 - 64mm; 4- cobble, 64 - 256mm; 5- boulder, > 256mm; 6- bedrock; 7- manmade

Bank Erosion: 0- not evident; 1- light fluvial; 2- moderate fluvial; 3- heavy fluvial / mass wasting

64. Comments (bank material variation, minor inflows, protection extent, etc.):

342 
65. Debris and Ice Is there debris accumulation?

$(Y$ or $N)$ 66. Where? $\mathbf{N}$

(1- Upstream; 2- At bridge; 3- Both)

67. Debris Potential ( 1- Low; 2- Moderate; 3- High)

68. Capture Efficiency 2 (1-Low; 2- Moderate; 3- High)

69. Is there evidence of ice build-up? 1 ( $Y$ or $N)$

Ice Blockage Potential $\underline{\mathbf{Y}}$

(1- Low; 2- Moderate; 3- High)

70. Debris and Ice Comments:

1

Trees along the left bank show scars up to the bridge deck level. Bridge does not constrict channel very much, therefore ice blockage potential should be minimal.

\begin{tabular}{|l|c|c|c|c|c|c|c|c|}
\hline Abutments & $\begin{array}{c}\text { 71. Attack } \\
\angle \text { (BF) }\end{array}$ & $\begin{array}{c}72 \text {. Slope } \angle \\
\text { (Qmax) }\end{array}$ & $\begin{array}{c}\text { 73. Toe } \\
\text { loc. (BF) }\end{array}$ & $\begin{array}{c}\text { 74. Scour } \\
\text { Condition }\end{array}$ & $\begin{array}{c}75 . \text { Scour } \\
\text { depth }\end{array}$ & $\begin{array}{c}\text { 76. Exposure } \\
\text { depth }\end{array}$ & 77. Material & 78. Length \\
\hline LABUT & & $\mathbf{2 0}$ & $\mathbf{9 0}$ & $\mathbf{2}$ & $\mathbf{1}$ & $\mathbf{0 . 5}$ & $\mathbf{0}$ & $\mathbf{9 0 . 0}$ \\
\hline RABUT & $\mathbf{1}$ & $\mathbf{0}$ & $\mathbf{9 0}$ & & & $\mathbf{2}$ & $\mathbf{0}$ & $\mathbf{3 3 . 0}$ \\
\hline
\end{tabular}

Pushed: $L B$ or RB

Toe Location (Loc.): 0- even, 1- set back, 2- protrudes

Scour cond.: 0- not evident; 1- evident (comment); 2- footing exposed; 3-undermined footing; 4- piling exposed; 5- settled; 6- failed

Materials: 1- Concrete; 2- Stone masonry or drywall; 3- steel or metal; 4- wood

79. Abutment comments (eg. undermined penetration, unusual scour processes, debris, etc.):

$-$

1

\#73: Both abutments are almost even.

\#75: Maximum depth of water is 1.0 feet.

80. Wingwalls:

Exist? Material? Scour Scour Exposure Angle? Length? Condition? depth? depth?

USLWW:

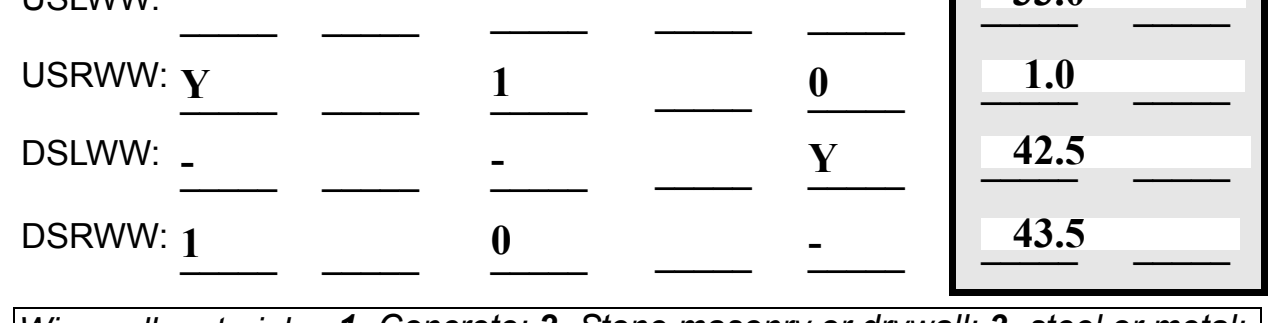

Wingwall materials: 1- Concrete; 2- Stone masonry or drywall; 3- steel or metal; 4- wood

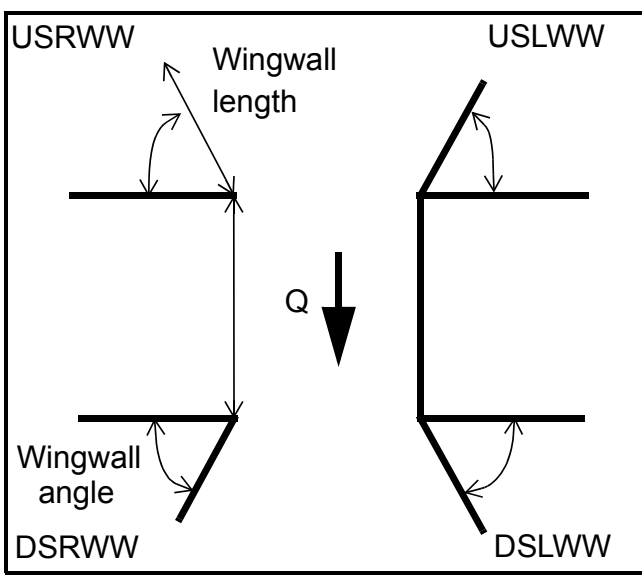

82. Bank / Bridge Protection:

\begin{tabular}{|l|l|l|l|l|l|l|l|l|}
\hline Location & USLWW & USRWW & LABUT & RABUT & LB & RB & DSLWW & DSRWW \\
\hline Type & - & $\mathbf{0}$ & $\mathbf{Y}$ & - & $\mathbf{1}$ & $\mathbf{1}$ & - & - \\
\hline Condition & $\mathbf{Y}$ & - & $\mathbf{1}$ & - & $\mathbf{1}$ & $\mathbf{2}$ & - & - \\
\hline Extent & $\mathbf{1}$ & - & $\mathbf{0}$ & $\mathbf{2}$ & $\mathbf{2}$ & $\mathbf{0}$ & $\mathbf{0}$ & - \\
\hline
\end{tabular}

Bank / Bridge protection types: 0- absent; 1- < 12 inches; 2- < 36 inches; 3- < 48 inches; 4- < 60 inches; 
83. Wingwall and protection comments (eg. undermined penetration, unusual scour processes, etc.):

-
-
-
-
-
2
1
1
2
1
1

\section{Piers:}

84. Are there piers? _ _ (Y or if $N$ type ctrl-n pr)

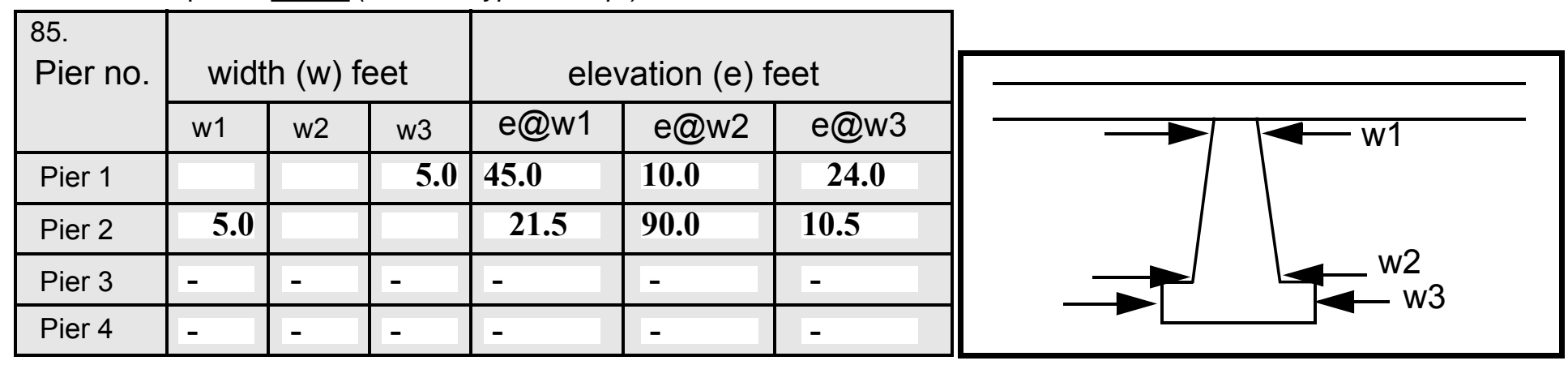

\begin{tabular}{|c|c|c|c|c|}
\hline Level 1 Pier Descr. & 1 & 2 & 3 & 4 \\
\hline 86. Location (BF) & & - & - & - \\
\hline 87. Type & & - & - & - \\
\hline 88. Material & & - & - & - \\
\hline 89. Shape & & - & - & - \\
\hline 90. Inclined? & & - & - & - \\
\hline 91. Attack $\angle(B F)$ & & - & - & - \\
\hline 92. Pushed & & - & - & - \\
\hline 93. Length (feet) & - & - & - & - \\
\hline 94. \# of piles & & - & - & - \\
\hline 95. Cross-members & & - & - & - \\
\hline 96. Scour Condition & & - & - & - \\
\hline 97. Scour depth & $\mathbf{N}$ & - & - & - \\
\hline 98. Exposure depth & - & - & - & - \\
\hline
\end{tabular}

LFP, LTB, LB, MCL, MCM, MCR, RB, RTB, RFP

1- Solid pier, 2- column, 3- bent

1-Wood; 2- concrete; 3- metal; 4- stone

1- Round; 2- Square; 3- Pointed

Y-yes; $N-$ no

$L B$ or $R B$

0- none; 1- laterals; 2- diagonals; 3- both

0- not evident; 1- evident (comment);

2- footing exposed; 3- piling exposed;

4- undermined footing; 5- settled; 6- failed 
99. Pier comments (eg. undermined penetration, protection and protection extent, unusual scour processes, etc.):

-
-
-
-
-
-
-
-
-

100.

\section{E. Downstream Channel Assessment}

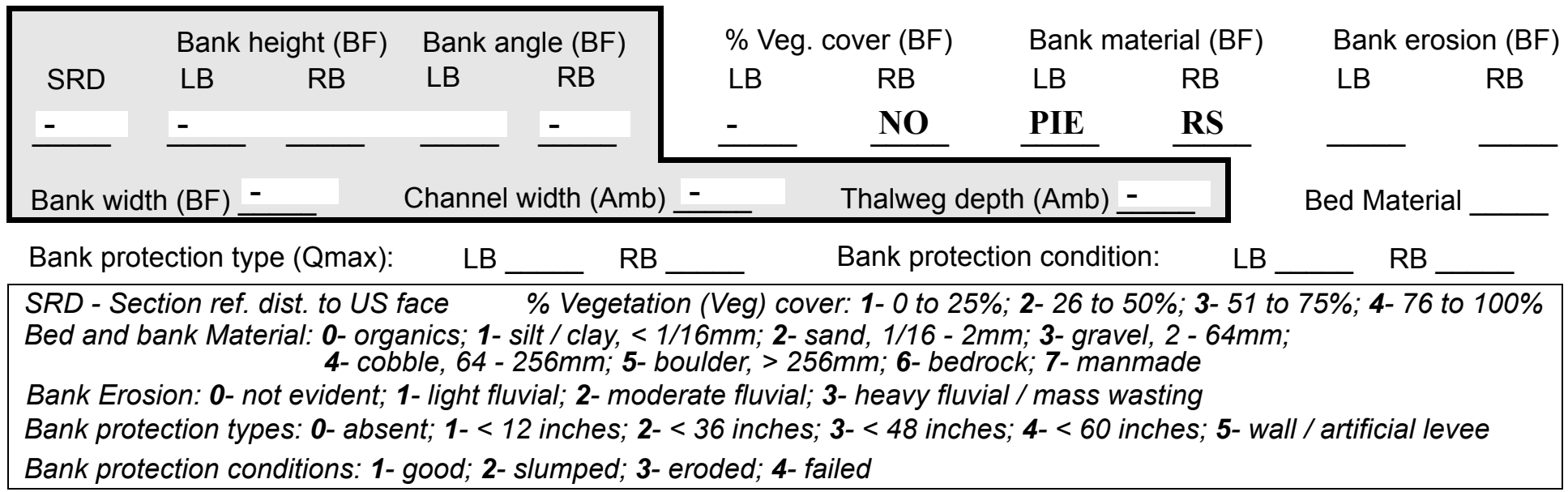

Comments (eg. bank material variation, minor inflows, protection extent, etc.):

1
1
7
7
1
1
345
2
2
1
1

The right bank protection extends from 15 feet under bridge to more than 230 feet downstream. The left bank protection extends from 20 feet downstream to more than 230 feet downstream.

101. Is a drop structure present? ___ ( $Y$ or $N$, if $N$ type ctrl-n ds) 102. Distance: ___ feet

103. Drop: __ feet 104. Structure material: On (1- steel sheet pile; 2- wood pile; 3- concrete; 4- other)

105. Drop structure comments (eg. downstream scour depth):

both banks, the bank material is boulder fill and concrete blocks were placed in order to extend the farmer's fields to the stream. 
Point bar extent: feet

(US, UB, DS) to feet $\underline{\mathbf{N}}$ (US, UB, DS) positioned \%LB to NO \%RB

Material: $\mathbf{D R}$

Point or side bar comments (Circle Point or Side; note additional bars, material variation, status, etc.):

\section{OP STRUCTURE}

Is a cut-bank present? (Y or if $N$ type ctrl- $n$ cb) Where? (LB or $R B)$

Mid-bank distance: $\underline{\mathbf{Y}}$

Cut bank extent: $\underline{\mathbf{1 9 5}}$ feet $\underline{\mathbf{2 0}}$ (US, UB, DS) to $\underline{\mathbf{1 2 0}}$ feet $\underline{\mathrm{DS}}$ (US, UB, DS)

Bank damage: 230 (1- eroded and/or creep; 2- slip failure; 3- block failure)

Cut bank comments (eg. additional cut banks, protection condition, etc.):

DS

0

40

345

Is channel scour present? Ref ( $Y$ or if $N$ type ctrl-n cs) Mid-scour distance: er to Scour dimensions: Length the Width upst Depth: rea Positioned $\underline{\mathbf{m}} \%$ LB to cha $\%$ RB

Scour comments (eg. additional scour areas, local scouring process, etc.):

nnel assessment for a description of this point bar which begins upstream and continues to just downstream of the bridge.

Are there major confluences? $\mathbf{Y}$ ( $Y$ or if $N$ type ctrl-n $m c)$

How many? $\underline{\mathbf{R B}}$

Confluence 1: Distance 100 Enters on $\underline{85}$ (LB or $R B)$

Type $\underline{\text { DS }}$

(1- perennial; 2- ephemeral)

Confluence 2: Distance 120 Enters on $\underline{\text { DS }}(L B$ or $R B)$

Type 1 (1- perennial; 2- ephemeral)

Confluence comments (eg. confluence name):

The maximum tree roots exposure and bank undercutting is located 100 feet downstream. Further downstream, the undermining diminishes.

\section{F. Geomorphic Channel Assessment}

107. Stage of reach evolution

1- Constructed

2- Stable

3- Aggraded

4- Degraded

5- Laterally unstable

6- Vertically and laterally unstable 
Y

10

15

4

0.5

0

10

The scour hole exists from 0 feet downstream to 15 feet downstream.

An additional scour hole from 120 feet downstream to 140 feet downstream exists behind a large boulder (6 feet in diameter). The maximum depth is 1.0 and maximum width is 8 feet. It is positioned $50 \% \mathrm{LB}$ to $90 \%$ RB.

$\mathbf{N}$ 


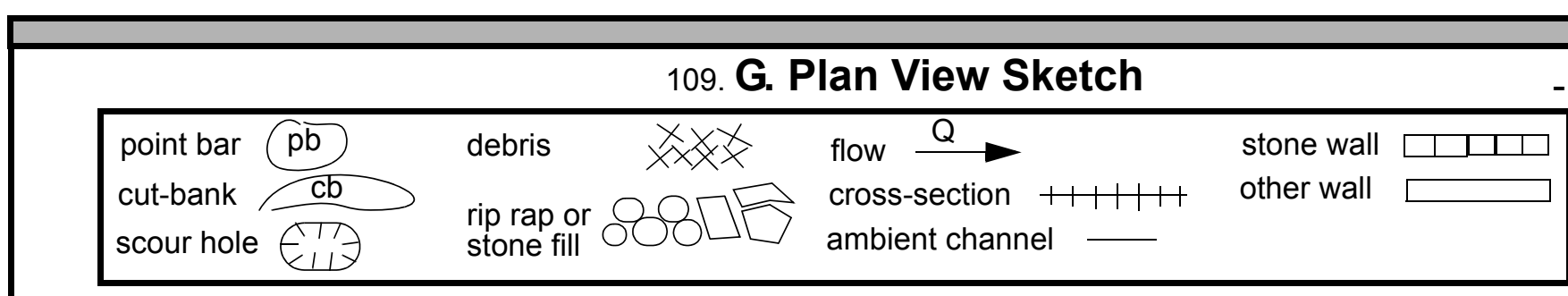


APPENDIX F:

SCOUR COMPUTATIONS 


\begin{tabular}{|c|c|c|c|}
\hline Structure Number: GRAFTH00020010 & & Town : & \\
\hline Road Number: $\quad$ TH 1 (VT 121) & & County: & Windhan \\
\hline Saxtons River & & & \\
\hline Initials EMB & Checked: & RLB & \\
\hline nalysis of contraction scour, live & -bed or $\mathrm{C}$ & lear wa & \\
\hline $\begin{array}{l}\text { Critical Velocity of Bed Material } \\
\mathrm{VC}=11.21 * \mathrm{Y} 1^{\wedge} 0.1667 * \mathrm{D} 50^{\wedge} 0.33 \text { with } \mathrm{Ss}\end{array}$ & $\begin{array}{l}\text { converted } \\
=2.65\end{array}$ & to Eng & \\
\hline (Richardson and others, 1995, p. 28 & eq. 16) & & \\
\hline pproach section & & & \\
\hline Characteristic & $100 \mathrm{yr}$ & $500 \mathrm{yr}$ & other \\
\hline Total discharge, cfs & 2520 & 3700 & 1900 \\
\hline Main Channel Area, ft2 & 346 & 373 & 242 \\
\hline Left overbank area, ft2 & 0 & 0 & 0 \\
\hline Right overbank area, ft2 & 603 & 837 & 0 \\
\hline Top width main channel, ft & 43 & 44 & 41 \\
\hline Top width L overbank, ft & 0 & 0 & 0 \\
\hline Top width $\mathrm{R}$ overbank, ft & 353 & 414 & 1 \\
\hline D50 of channel, ft & 0.1872 & 0.1872 & 0.1872 \\
\hline D50 left overbank, ft & -- & -- & -- \\
\hline D50 right overbank, ft & -- & -- & -- \\
\hline $\mathrm{y}_{1}$, average depth, $\mathrm{MC}$, ft & 8.0 & 8.5 & 5.9 \\
\hline y1, average depth, LOB, ft & ERR & ERR & ERR \\
\hline $\mathrm{Y}_{1}$, average depth, ROB, ft & 1.7 & 2.0 & 0.0 \\
\hline Total conveyance, approach & 74078 & 98795 & 21655 \\
\hline Conveyance, main channel & 37393 & 41814 & 21653 \\
\hline Conveyance, LOB & 0 & 0 & 0 \\
\hline Conveyance, ROB & 36685 & 56981 & 2 \\
\hline Percent discrepancy, conveyance & 0.0000 & 0.0000 & 0.0000 \\
\hline Qm, discharge, MC, cfs & 1272.0 & 1566.0 & 1899.8 \\
\hline Q1, discharge, LOB, Cfs & 0.0 & 0.0 & 0.0 \\
\hline Qr, discharge, ROB, cfs & 1248.0 & 2134.0 & 0.2 \\
\hline $\mathrm{Vm}$, mean velocity $\mathrm{MC}$, $\mathrm{ft} / \mathrm{s}$ & 3.7 & 4.2 & 7.9 \\
\hline Vl, mean velocity, LOB, ft/s & ERR & ERR & ERR \\
\hline Vr, mean velocity, $R O B, f t / s$ & 2.1 & 2.5 & ERR \\
\hline Vc-m, crit. velocity, $M C$, ft/s & 9.1 & 9.2 & 8.6 \\
\hline Vc-l, crit. velocity, LOB, ft/s & ERR & ERR & ERR \\
\hline Vc-r, crit. velocity, ROB, ft/s & ERR & ERR & ERR \\
\hline
\end{tabular}

\section{Results}

Live-bed(1) or Clear-Water(0) Contraction Scour?

Main Channel

0

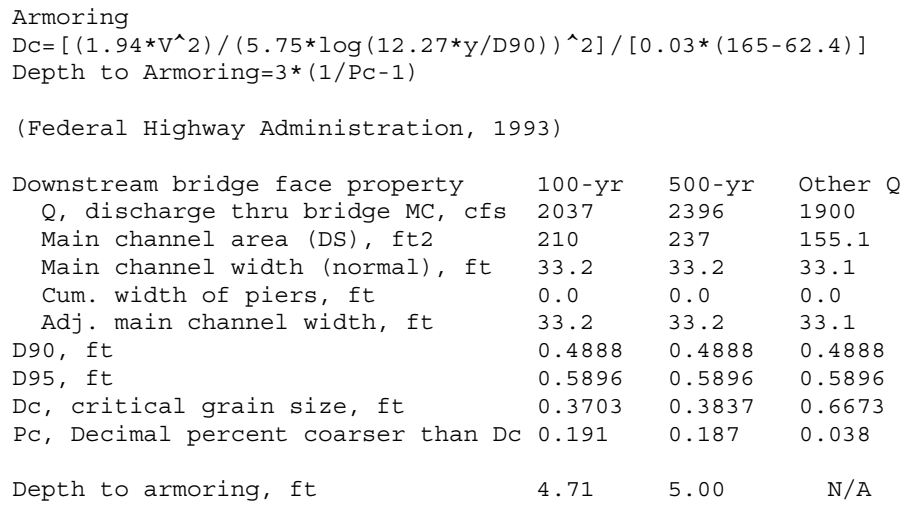


Clear Water Contraction Scour in MAIN CHANNEL

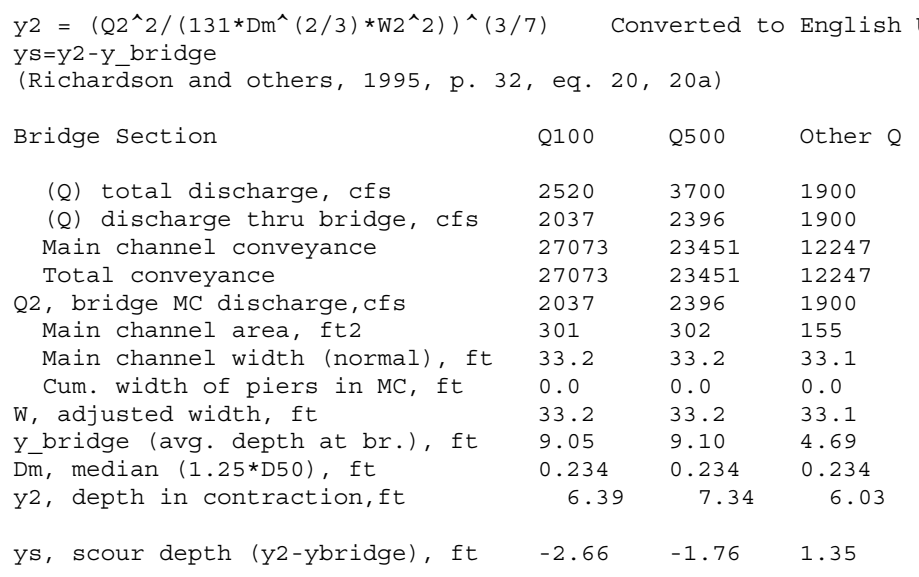

Pressure Flow Scour (contraction scour for orifice flow conditions)

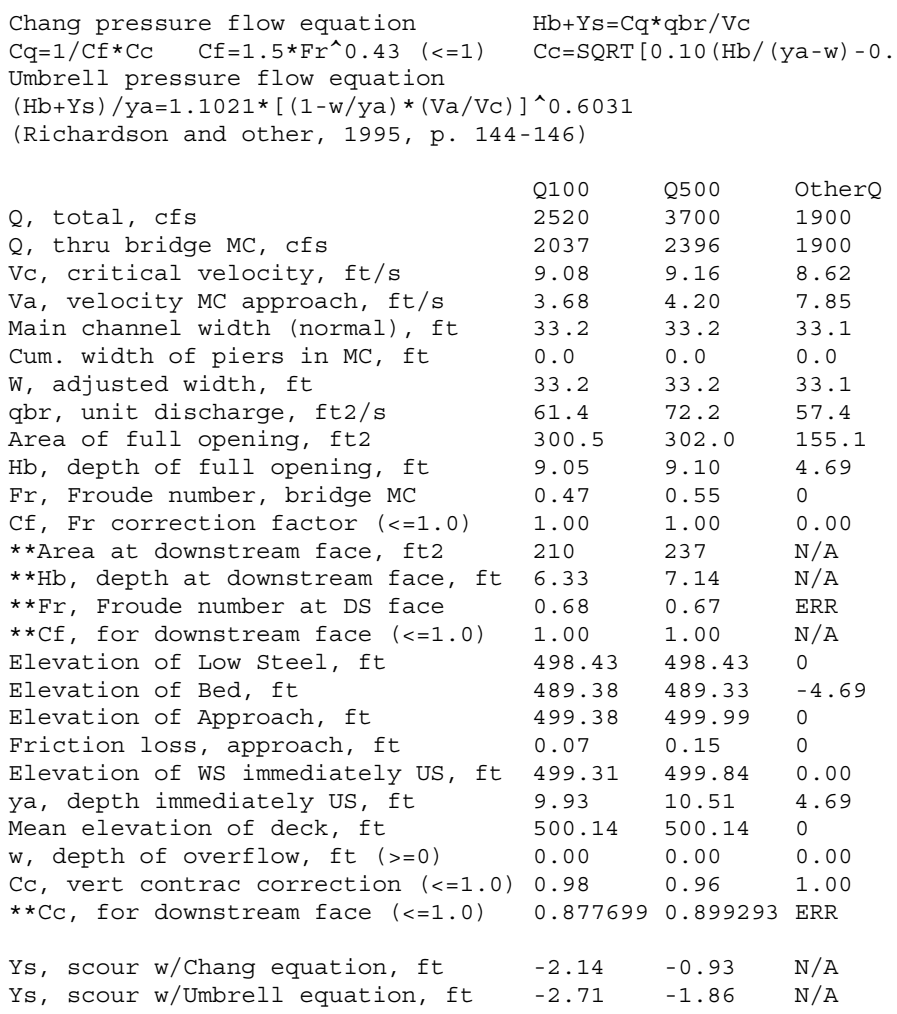

**=for UNsubmerged orifice flow using estimated downstream bridge face properties.

**Ys, scour w/Chang equation, ft $1.38 \quad 1.63 \quad \mathrm{~N} / \mathrm{A}$

**Ys, scour w/Umbrell equation, ft $0.02 \quad 0.10 \quad$ ERR

In UNsubmerged orifice flow, an adjusted scour depth using the Laursen equation results and the estimated downstream bridge face properties can also be computed (ys=y2-ybridgeDs)

y2, from Laursen's equation, ft $6.39 \quad 7.34 \quad 7.24$

WSEL at downstream face, ft $495.66 \quad 496.48 \quad$ - -

Depth at downstream face, ft $6.33 \quad 7.14 \quad$ N/A

Ys, depth of scour (Laursen), ft $0.06 \quad 0.20 \quad \mathrm{~N} / \mathrm{A}$ 


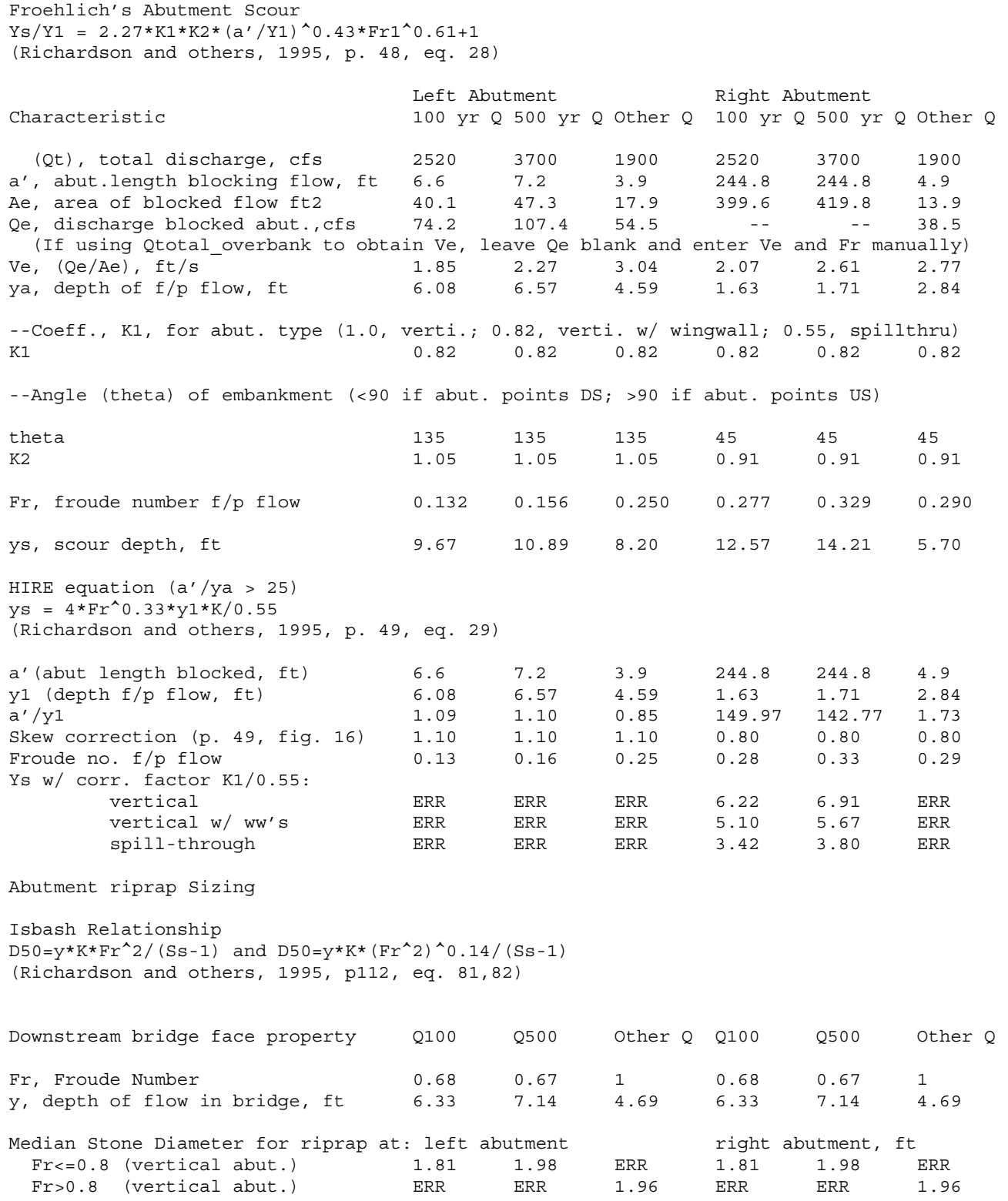

